\title{
Targeting tumor-associated carbohydrate antigens: a phase I study of a carbohydrate mimetic-peptide vaccine in stage IV breast cancer subjects
}

\author{
Laura F. Hutchins ${ }^{1,6}$, Issam Makhoul ${ }^{1,6}$, Peter D. Emanuel ${ }^{1,6}$, Angela Pennisi ${ }^{1,6}$, Eric \\ R. Siegel ${ }^{2}$, Fariba Jousheghany ${ }^{3}$, Xueyan Guo ${ }^{4}$, Anastas D. Pashov ${ }^{5}$, Behjatolah \\ Monzavi-Karbassi ${ }^{3,6}$ and Thomas Kieber-Emmons ${ }^{3,6}$ \\ ${ }^{1}$ Departments of Medicine, University of Arkansas for Medical Sciences, Little Rock, Arkansas, USA \\ ${ }^{2}$ Departments of Biostatistics, University of Arkansas for Medical Sciences, Little Rock, Arkansas, USA \\ ${ }^{3}$ Departments of Pathology, University of Arkansas for Medical Sciences, Little Rock, Arkansas, USA \\ ${ }^{4}$ Department of Gastroenterology, Third Affiliated Hospital of Xi'an Jiaotong University, Xi'an, Shaanxi, China \\ ${ }^{5}$ Stephan Angelov Institute of Microbiology, Bulgarian Academy of Sciences, Sofia, Bulgaria \\ ${ }^{6}$ Winthrop P. Rockefeller Cancer Institute, Little Rock, Arkansas, USA \\ Correspondence to: Thomas Kieber-Emmons, email: tke@uams.edu
}

Keywords: tumor-associated carbohydrate antigens, cancer vaccine, clinical trial, breast cancer, peptide mimotopes

Received: August 23, $2017 \quad$ Accepted: October 10, $2017 \quad$ Published: October 23, 2017

Copyright: Hutchins et al. This is an open-access article distributed under the terms of the Creative Commons Attribution License 3.0 (CC BY 3.0), which permits unrestricted use, distribution, and reproduction in any medium, provided the original author and source are credited.

\section{ABSTRACT}

Tumor-associated carbohydrate antigens (TACAs) support cell survival that could be interrupted by anti-TACA antibodies. Among TACAs that mediate cell survival signals are the neolactoseries antigen Lewis $Y$ (LeY) and the ganglioside GD2. To induce sustained immunity against both LeY and GD2, we developed a carbohydrate mimicking peptide (CMP) as a surrogate pan-immunogen that mimics both. This CMP, referred to as P10s, is the $\mathrm{N}$-terminal half of a peptide vaccine named P10s-PADRE, the C-terminal half of which (PADRE) is a Pan-T-cell epitope. A Phase I dose-escalation trial of P10s-PADRE plus adjuvant MONTANIDE ${ }^{\mathrm{TM}}$ ISA 51 VG was conducted in subjects with metastatic breast cancer to test 300 and $500 \mu \mathrm{g} /$ injection in two cohorts of 3 subjects each. Doses of the P10s-PADRE vaccine were administered to research participants subcutaneously on weeks 1, 2, 3, 7 and 19. Antibody responses to P10s, GD2, and LeY were measured by ELISA. The P10s-PADRE vaccine induced antibodies specifically reactive with P10s, LeY and GD2 in all 6 subjects. Serum antibodies displayed Caspase3-dependent apoptotic functionality against LeY or GD2 expressing breast cancer cell lines. Immunization with the P10s-PADRE vaccine was well-tolerated and induced functional antibodies, and the data suggest potential clinical benefit.

\section{INTRODUCTION}

Aberrant glycosylation is a common phenotypic change of cancer cells, arising from clustered presentation on a cell surface or through modified synthesis [1]. Tumor-Associated Carbohydrate Antigens (TACAs) mediate important signaling effects that underlie their role in tumor biology. Since TACAs are expressed on glycoproteins and glycolipids that regulate multiple cellular/signaling pathways, targeting the proliferative machinery of malignant cells by anti-TACA therapies is an attractive concept to combat cancer. Monoclonal antibodies (mAbs) directed to some TACAs, like those directed to the ganglioside GD2 and the neolactoseries antigen Lewis $\mathrm{Y}$ (LeY), are known to inhibit cell signaling that influences cell survival [2-3]. Monoclonal antibodies to these oncotargets are in clinical trials [2] or have been approved [3]. The induction of antibodies to these antigens and related types would therefore be of clinical benefit by providing sustained immunity to inhibit metastatic outgrowth.

Immune tolerance to TACAs has severely restricted the usefulness of most TACAs in immunotherapy development, requiring multiple approaches to direct the 
immune response [4-6]. We have developed potential TACA-directed vaccines based on carbohydrate-mimetic peptides (CMPs) that induce anti-tumor-reactive humoral [7-9] and cellular [10, 11] responses in mice. These CMPs are Pan-immunogens, developed to induce antibodies reactive with multiple TACAs when immunizing with a single agent [7-10, 12].

We have moved one of these CMPs, with the sequence WRYTAPVHLGDG (referred to as P10s) conjugated to the Pan-T-cell epitope PADRE, into an early-phase clinical trial in Stage IV breast cancer subjects. This CMP was designed to mimic and induce responses to the ganglioside GD2 [9] and the LeY antigen $[12,13]$. In particular, LeY has a very restricted tissue distribution because it is a fetal antigen. Historically, LeY was found overexpressed on a large percentage of tumors of epithelial origin including those originating from colon, breast, lung, prostate and ovary [14-17]. The LeY antigen enhances the invasion and metastasis of cancer cells, and its high expression is associated with decreased survival in lymph node-negative breast carcinomas [18]. The LeY antigen is purported to regulate the expression of cell cycle-related factors through ERK/MAPK and PI3K/Akt signaling pathways to promote cell proliferation $[19,20]$. LeY expression is therefore considered associated with drug resistance [21].

Likewise, anti-GD2 antibodies can downmodulate $\mathrm{PI} 3 \mathrm{~K} /$ Akt signaling pathways $[22,23]$. As a potential target for anti-tumor immunotherapy, GD2 is ideal due to its high expression on several tumor types and its restricted expression on normal tissue. The National Cancer Institute pilot program for the prioritization of the most important cancer antigens ranks GD2 as \#12 out of 75 potential targets for cancer therapy [24]. In fact, GD2 comes in at \#6 when considering antigens that are directly targetable in the circulation or on the cell surface. GD2 is expressed on breast and other cancer stem cells [25-27]. The recently demonstrated involvement of the GD2/c-Met axis in estrogen receptor (ER)-negative breast-cancer aggressiveness strongly supports anti-GD2 immunotherapeutic approaches for treatment of breast cancer, especially in subgroups of breast cancer subjects clustering on very aggressive breast cancer subtypes, such as triple-negative and metaplastic variants [28-30]. In addition, gangliosides of the b-series, which includes GD2/GD3, are demonstrated at higher levels in the sera of breast-cancer subjects [31]. Consequently, the induction of antibodies to LeY or GD2 has the potential to interfere with cancer cell-survival signals.

To test the feasibility of inducing proapoptotic antibodies reactive with LeY and GD2, we immunized advanced breast-cancer subjects with the P10s-PADRE vaccine. We characterized tolerability, the feasibility of the immunization schedule, and the humoral response to P10s-PADRE in two cohorts (3 subjects each) at different immunogen doses. The ability of the vaccine-induced antibodies to affect survival of human breast cancer cell lines was examined. Our results provide further insight into the relative importance of inducing humoral responses to TACAs and the potential use of P10s as an immunogen to induce immune responses that could have clinical benefit.

\section{RESULTS}

\section{Subject characteristics}

Sixteen subjects were consented into the study. Six subjects $(37.5 \%)$ failed screening because of a lack of delayed-type hypersensitivity (DTH) response to two recall antigens, while three subjects (18.8\%) failed screening for other reasons. Only one subject declined to continue with the study, and never completed pre-study/ screening to determine eligibility. The six subjects who did enroll successfully completed their immunization course of 5 immunizations over 23 weeks - hyperimmunization on weeks 1, 2, and 3, another immunization on week 7 , and a boost immunization at week 19. No toxicities were observed. A summary of the subjects' status and response to the P10s-PADRE vaccination is listed in Tables $1 \mathrm{~A}$ and $1 \mathrm{~B}$.

\section{Immunization with P10s-PADRE induced anti- $P 10$ s antibody response}

The most important feature of the immune response to the P10s-PADRE vaccine is the observation that immunized subjects generated an immune response to the Multiple Antigenic Peptide (MAP) version of P10s, which is free of the PADRE conjugate. The multivalent nature of MAPs allow for a more faithful mimicry of the clustered structures of cell-surface glycans that is extremely useful for testing glycan recognition in solid phase. We observed an increase in IgG and IgM binding to the P10s MAP in subjects' postimmune sera compared to their preimmune sera (Figure 1). A similar binding pattern to the MAP peptide was observed using plasma samples (Supplementary Figure 1). Anti-P10s IgG and IgM reactivity surged from week 4 to week 7 of the study in all subjects except subject \#6, in whom it was already surging at week 4. The increases of IgG at week 7 compared to preimmune ranged from 31 folds (in subject \#2) to 256 folds (in subjects \#5 and \#6), and the titers in subsequent weeks showed little change from their week-7 values. Endpoint titers were tested in yearly follow-up serum samples available from 4 out of 6 subjects vaccinated. The titers dropped but were still considered high a year after final immunization but fell significantly after the second year (Supplementary Table 1). The IgM response was short-lived, as a dramatic decrease was observed by week 19. The cohort immunized with the higher dose of vaccine displayed higher normalized IgG endpoint titers 
Table 1A: Patient characteristics of all consented subjects

\begin{tabular}{|c|c|c|c|c|c|c|c|}
\hline Subject & $\begin{array}{l}\text { Eligibility } \\
(\mathbf{y} / \mathbf{n})\end{array}$ & $\begin{array}{l}\text { Reason } \\
\text { Ineligible }\end{array}$ & Age & $\begin{array}{l}\text { Performance } \\
\text { Status (ECOG) }\end{array}$ & $\begin{array}{l}\text { Lines of Prior } \\
\text { Endocrine } \\
\text { Therapy }\end{array}$ & $\begin{array}{l}\text { Lines of Prior } \\
\text { Chemotherapy }\end{array}$ & $\begin{array}{l}\text { ER/PR/Her2 } \\
\text { Status }\end{array}$ \\
\hline 39601 & $\bar{y}$ & & 77 & 0 & 2 & 1 & $+/+/-$ \\
\hline 39603 & $\mathrm{y}$ & & 45 & 0 & 0 & 2 & $+/-/-$ \\
\hline 39604 & $\mathrm{y}$ & & 49 & 0 & 0 & 1 & $+/-/+$ \\
\hline 39608 & $\mathrm{y}$ & & 50 & 1 & 3 & 1 & $+/+/-$ \\
\hline 39609 & $\mathrm{y}$ & & 67 & 0 & 2 & 2 & $+/-/-$ \\
\hline 39616 & $\mathrm{y}$ & & 51 & 0 & 0 & 1 & $-/-/+$ \\
\hline 39610 & $\mathrm{n}$ & $\begin{array}{l}\text { withdrew } \\
\text { consent }\end{array}$ & 44 & 0 & 2 & 0 & $+/+/-$ \\
\hline 39611 & $\mathrm{n}$ & DTH neg & 67 & & 1 & 1 & $+/+/-$ \\
\hline 39614 & $\mathrm{n}$ & DTH neg & 73 & 0 & 2 & 1 & $+/+/-$ \\
\hline 39606 & $\mathrm{n}$ & DTH neg & 61 & & 0 & 3 & $-1-1-$ \\
\hline 39605 & $\mathrm{n}$ & DTH neg & 67 & 0 & 1 & 2 & $+/+/-$ \\
\hline 39613 & $\mathrm{n}$ & $\begin{array}{l}\text { disease } \\
\text { progression }\end{array}$ & 44 & 0 & 0 & 1 & $-1-/-$ \\
\hline 39615 & $\mathrm{n}$ & $\begin{array}{l}\text { disease } \\
\text { progression }\end{array}$ & 65 & & 2 & 2 & $+/+/-$ \\
\hline 39612 & $\mathrm{n}$ & DTH neg & 62 & 1 & 0 & 1 & $-1-1-$ \\
\hline 39607 & $\mathrm{n}$ & DTH neg & 54 & 0 & 0 & 2 & $-1-1-$ \\
\hline 39602 & $\mathrm{n}$ & elevated LFT & 61 & 3 & 2 & 0 & $+/+/-$ \\
\hline
\end{tabular}

Table 1B: Systemic therapy, clinical responses, and immune responses of enrolled subjects

\begin{tabular}{|c|c|c|c|c|c|}
\hline \multirow{2}{*}{$\begin{array}{c}\text { Dose of } \\
\text { peptide } \\
(\mu g) \text { per } \\
\text { vaccination }\end{array}$} & \multirow[t]{2}{*}{ Subject } & \multirow{2}{*}{$\begin{array}{l}\text { Standard } \\
\text { systemic } \\
\text { therapy }\end{array}$} & \multirow{2}{*}{$\begin{array}{c}\text { Time to } \\
\text { Progression, or best } \\
\text { RECIST response } \\
\text { at last contact if not } \\
\text { progressed }\end{array}$} & \multicolumn{2}{|c|}{ Immune responses } \\
\hline & & & & $\begin{array}{l}\text { Immunized serum and } \\
\text { plasma binding to MAP } \\
\text { (ELISA) }\end{array}$ & $\begin{array}{c}\text { Immunized serum and } \\
\text { plasma toxicity on cancer } \\
\text { cells }\end{array}$ \\
\hline \multirow[t]{3}{*}{300} & $\begin{array}{l}39601 \\
(\# 1)\end{array}$ & Denosumab & 16 months & Yes & Yes \\
\hline & $\begin{array}{l}39603 \\
(\# 2)\end{array}$ & $\begin{array}{l}\text { Carboplatin } \\
\text { and } \\
\text { Gemcitabine }\end{array}$ & 4 months & Yes & Yes \\
\hline & $\begin{array}{l}39604 \\
(\# 3)\end{array}$ & $\begin{array}{l}\text { Vinorelbine } \\
\text { and } \\
\text { Trastuzumab }\end{array}$ & 12 months & Yes & Yes \\
\hline \multirow[t]{3}{*}{500} & $\begin{array}{l}39608 \\
(\# 4)\end{array}$ & Zometa & 8 months & Yes & Yes \\
\hline & $\begin{array}{l}39609 \\
(\# 5)\end{array}$ & Faslodex & $\mathrm{SD}^{\ddagger}$ at 54 months & Yes & No $†$ \\
\hline & $\begin{array}{l}39616 \\
(\# 6)\end{array}$ & Trastuzumab & $\mathrm{CR}^{\ddagger}$ at 50 months & Yes & Yes \\
\hline
\end{tabular}

$\dagger$ Due to high background toxicity in preimmune plasma from this subject, no significant increase in plasma toxicity was observed. A close look at the subject's calendar indicated that a Faslodex dose was applied two days before her preimmune blood draw. $\$$ SD and CR respectively mean Stable Disease and Complete Response via RECIST v1.1 criteria. 
(Figure 1). In nonparametric repeated-measures analysis for IgG-reactive serum, the main effects of dose and week were statistically significant (both $P$ values $<.0001$ ), but the dose $\times$ week interaction was not $(P=0.40)$ (Table 2$)$. The data suggest that 3 immunizations are enough to generate high titers of anti-P10s IgG antibodies in both serum and plasma samples. The data also suggest that $500 \mu \mathrm{g}$ per immunization may lead to higher antibody titers and a stronger immune response compared to immunization with $300 \mu \mathrm{g}$ per injection.

\section{P10s-PADRE-immunized serum reacted with both GD2 and LeY antigens}

Since P10s is a mimic of both LeY and GD2, we examined whether postimmune serum binds to these antigens. We observed a similar pattern of reactivity of postimmune serum with both glycans (Table 3). The reactivity patterns of $\mathrm{P} 10 \mathrm{~s}$-induced serum antibodies with the glycan antigens in the ELISA assay parallel those from our preclinical studies [9]. The IgG fraction of pre- and postimmune sera was purified and tested for their binding to P10s-MAP, LeY, and GD2 (Figure 2). IgG from immunized serum reacted with P10s-MAP (Figure 2A) and displayed higher binding to both GD2 and LeY glycans than the IgG purified from the preimmune serum (Figure 2B, 2C). No differences between binding of preimmune and postimmune purified IgG to $\alpha 2,8$-sialic acid, used as negative control, was detected (Figure 2D).

\section{Immunized serum inhibited the growth of breast cancer cells in vitro}

The real goal of effective immune therapy that directly targets cancer cells is to show that induced immune responses can result in tumor-cell death. We have shown previously that immunization with a plant lectin-reactive mimotope led to generation of apoptotic antibodies in a mouse model [8]. Anti-LeY and -GD2 antibodies are expected to negatively affect tumor-cell viability through induction of apoptosis and inhibition of growth [19, 23, 32, 33]. Therefore we examined whether serum antibodies from immunized subjects affect viability of human breast cancer cell lines in vitro. MDA-MB-231 (triple negative), HCC1954 (Her2-positive), MCF7 (ERpositive,) and ZR-75-1 (ER-positive) cell lines were chosen to examine binding and functionality of serum antibodies. MDA-MB-231 cells are known to express the GD2 ganglioside [28, 34] (Supplementary Figure 2A). HCC1954, MCF-7, and ZR-75-1 cell lines are LeY positive (Supplementary Figure 2B, 2C and 2D).

Plasma antibodies from P10s-vaccine immunized subjects displayed an increase in binding to both HCC1954 and MDA-MB-231 cell lines with mean \pm SD of $892 \pm$ $673(P=0.023)$ and $230 \pm 140(P=0.010)$, respectively. Binding for the representative pre- and postimmune plasmas from subject 6 is demonstrated (Figures 3A, 3B). The effect of P10s-induced antibodies on the viability of each cell line was tested by adding pre- and postimmune plasma to culture medium. Postimmune plasma significantly suppressed the viability of HCC1954, MDA-MB-231, and ZR-75-1 cells in vitro (Figures $3 \mathrm{C}, 3 \mathrm{D}, 3 \mathrm{E}$ ). The postimmune-induced decrease in viability among the 6 subjects had an average (standard deviation) of 26\% (24\%) towards HCC1954, 30\% (28\%) towards MDA-MB-231, and 22\% (19\%) towards ZR-75-1, and all decreases were statistically significant ( $P=0.047, P=0.044$, and $P=0.040$, respectively). In contrast, we observed no significant plasma effect on viability of MCF-7 cells (Figure 3F). However, postimmune plasma from all 6 subjects reacted well with both MCF-7 (Figure 3G) and ZR-75-1 (Figure 3H) cell lines. The data suggest that binding is required but not enough to affect

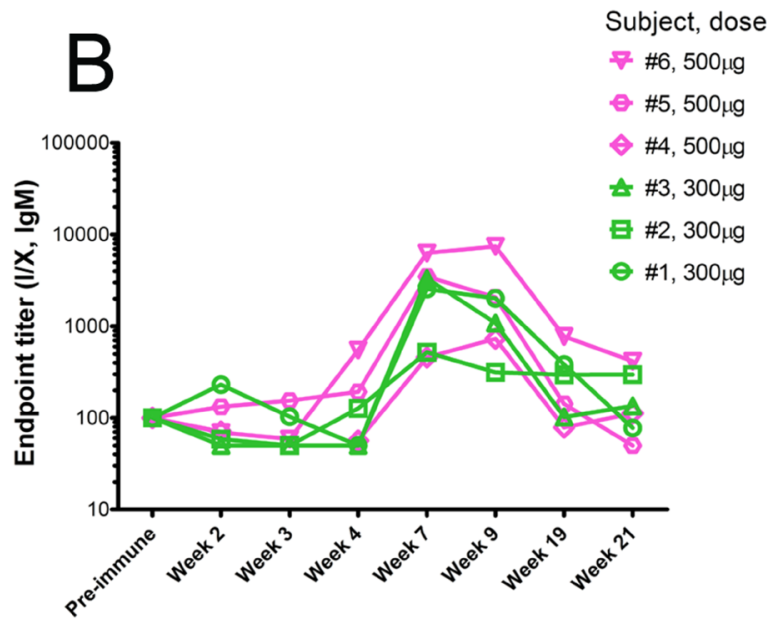

Figure 1: Reactivity of immunized subjects' serum antibodies against P10s. ELISA plates were coated with the multivalentantigen peptide (MAP) version of P10s, and reactivity of two-fold serial dilutions of sera from the weeks indicated on the horizontal axes was detected by HRP-conjugated anti-human $\operatorname{IgG}(\mathbf{A})$ and $\operatorname{IgM}(\mathbf{B})$. Normalized anti-peptide endpoint titers were estimated as described in the Methods section. 
Table 2: Non-parametric repeated-measures analysis of endpoint titer with Dose as the betweensubject effect and Week as the within-subject effect

\begin{tabular}{llll}
\hline Source & $\mathbf{D F}^{\dagger}$ & $\mathbf{F}^{\ddagger}$ & $\boldsymbol{P}$-value \\
\hline Dose & 1 & 38.9 & $<0.0001$ \\
Week & 2.93 & 27.22 & $<0.0001$ \\
Dose $\times$ Week & 2.93 & 0.98 & 0.40 \\
\hline
\end{tabular}

$\dagger$ :Degrees of Freedom $\uparrow$ :the ANOVA-Type Statistic of Brunner et al. [33] which approximately follows the central $F(\mathrm{DF}, \infty)$ distribution.

cell viability. We also examined serum functionality on the normal epithelial cell line MCF-10A and did not detect any differences in viability of cells incubated with pre- and postimmune plasma (Supplementary Figure 3), a result that suggests cancer-cell specificity for postimmune antibodies and parallels those from our mouse studies showing a lack of immunopathology on normal epithelial tissues $[9,35]$.

These data demonstrate that inhibitory effect toward MDA-MB-231, HCC1954, and ZR-75-1 cell lines was > 10 percentage points higher in the postimmune antibodies from 5 of the 6 subjects compared to their preimmune antibodies. Subject 5 displayed an unusually high growthinhibitory background in her preimmune serum. To understand whether this high background is attributed to serum $\operatorname{IgG}$, we used purified $\operatorname{IgG}$ fractions from this particular subject and examined their effect on MDAMB-231 and HCC1954 cells. Purified IgG fractions behaved as expected, displaying a significant decrease in viability in both cell lines tested upon treatment with postimmune $\operatorname{IgG}$ fraction (Figure 3I).
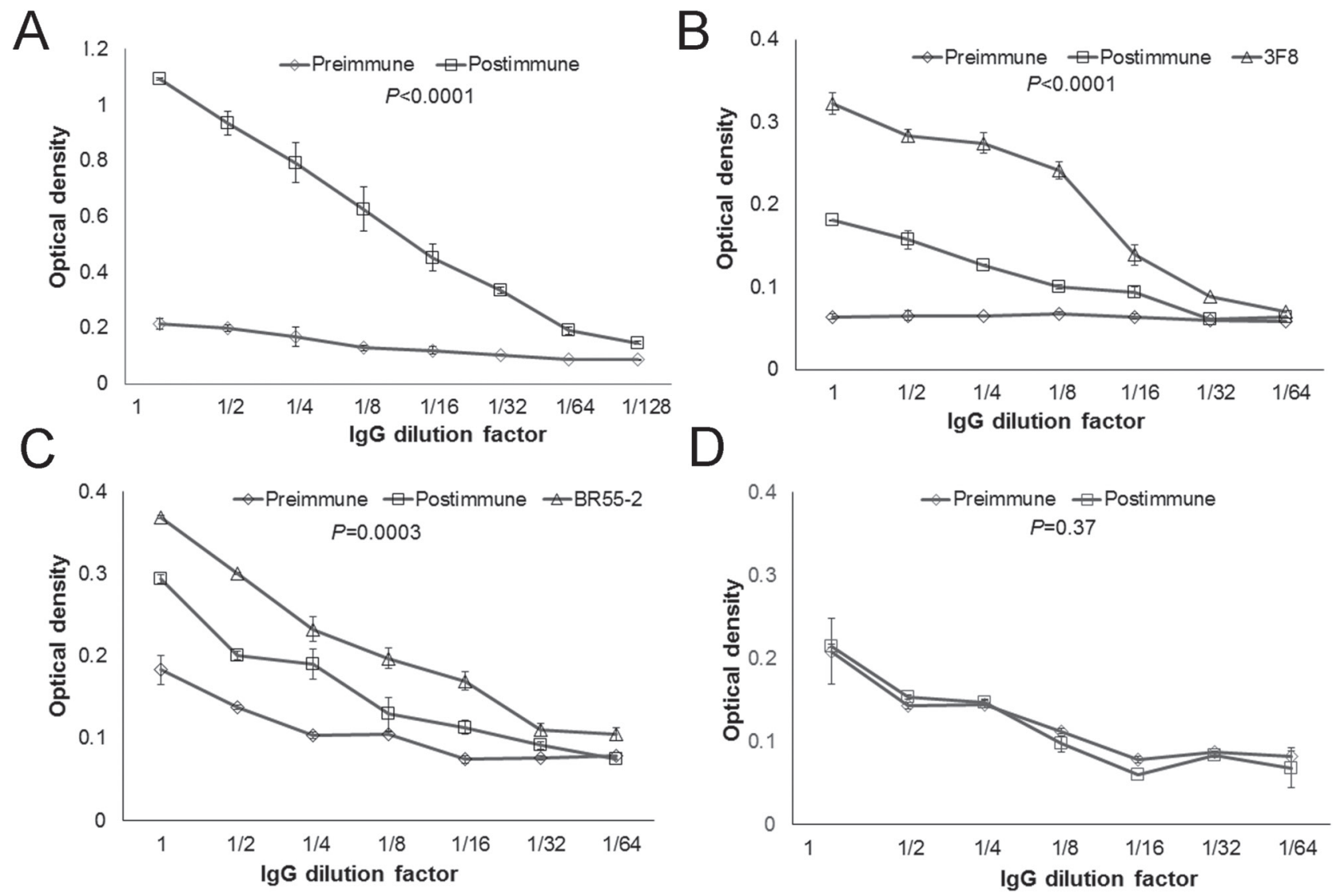

Figure 2: IgG fraction of serum antibodies bind to both GD2 and LeY antigens. IgG fraction of pre- and post-immune sera was enriched. ELISA plates then were coated with P10s-MAP (A), GD2 (B), LeY (C), and $\alpha 2,8$-sialic acid (D) antigens and serially diluted purified IgG was added to wells. The starting concentration for the IgG fraction was $120 \mu \mathrm{g} / \mathrm{ml}$. The starting concentration for the $\mathrm{mAbs}$ was $20 \mu \mathrm{g} / \mathrm{ml}$. The binding was visualized after addition of HRP-conjugated anti-human IgG. $P$ values comparing pre and postimmune dilution curves for each panel are shown. Symbols \pm error bars at each dilution factor denote the Means \pm SD of three experiments. Serum samples from Subjects 4, 5 and 6 were tested. We observed similar reactivity pattern for the subjects tested and the data for IgG fraction of serum from subject 6 is shown in this figure. 


\section{The effect of P10s-PADRE-induced immune serum on cell viability was caspase-3-dependent}

As shown above, both MCF-7 and HCC1954 cells overtly express LeY antigen, and postimmune induced antibodies bind to both cell lines. Thus, it is not clear why immune antibodies are effective on HCC1954 but not on MCF-7 cells. MCF-7 cells are known to have a dysfunctional caspase-3, [36] and a lack of growth- inhibitory activity could be due to caspase- 3 deficiency in this cell line. Our previously published data [37], through testing for Annexin V-FITC/PI on serum-treated MDAMB-231 cells, implicated apoptosis in P10s-induced antibody-mediated growth inhibition. If the induction of apoptosis is caspase-3-dependent, then apoptotic antibodies do not affect cells deficient in caspase-3 activity. We next tested the anti-LeY antibody BR55-2's functionality against LeY-positive HCC1954 and MCF-7
A
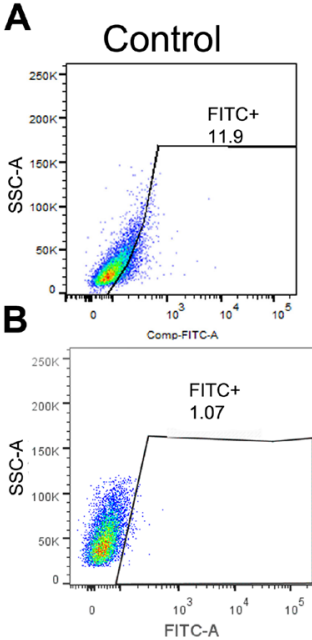

C $\quad$ HCC1954 cells

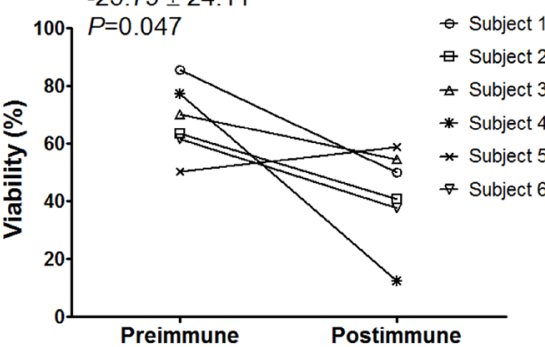

E $\quad$ ZR-75-1 cells

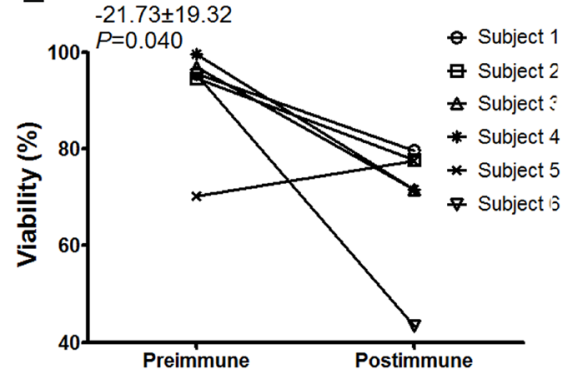

Preimmune
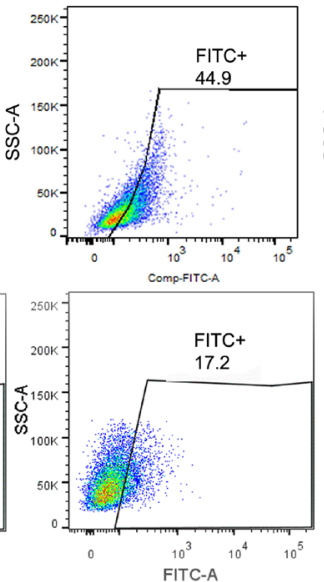
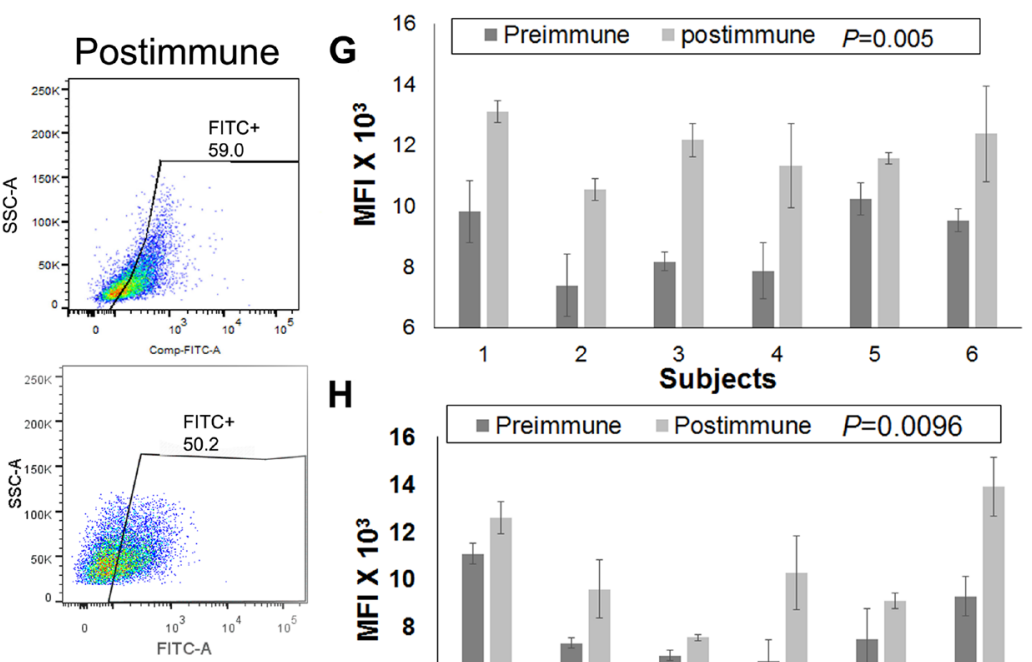

H
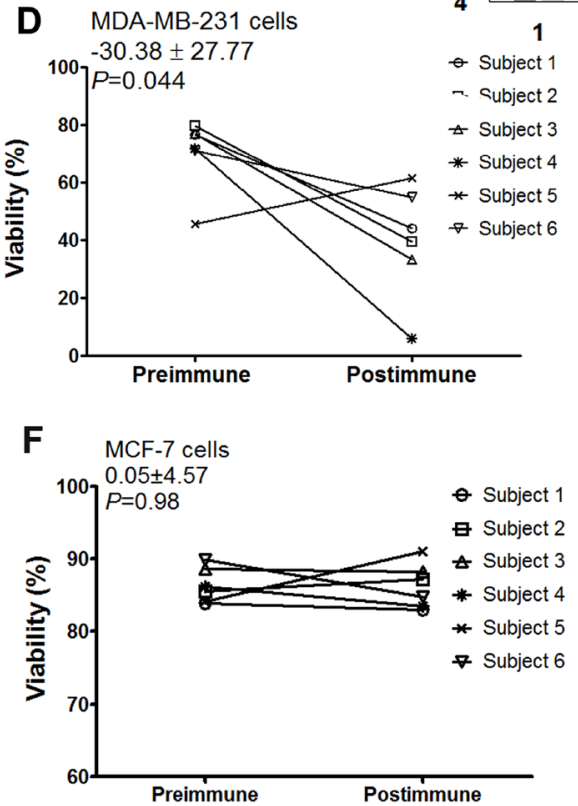

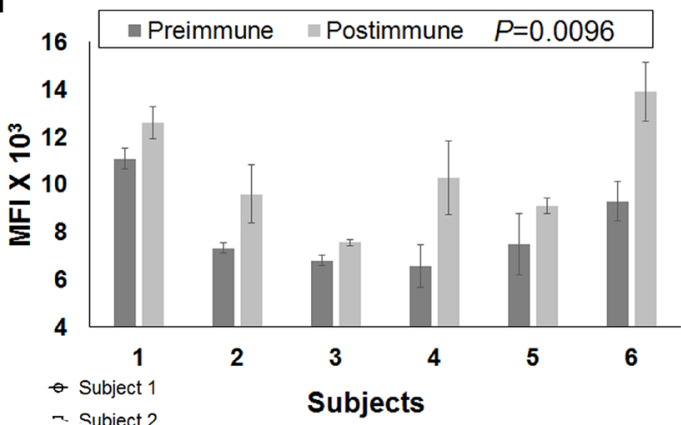

I

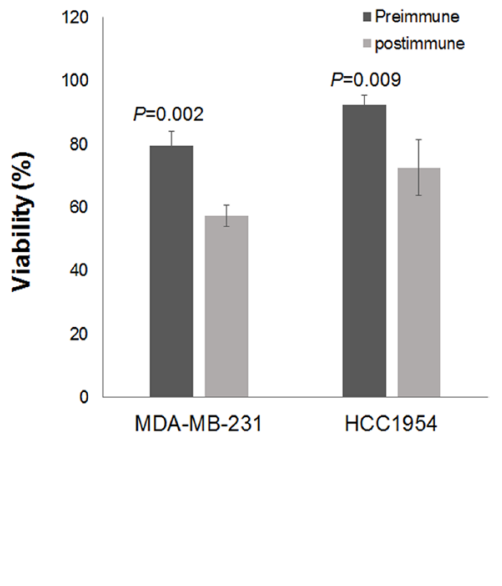

Figure 3: P10s-PADRE induces antibodies that react with cells and negatively affect viability of cells. Plasma samples from a representative subject (subject 6) bind to HCC1954 (A) and MDA-MB-231 (B) cells, Plasma derived from 5 out of 6 subjects negatively affect viability of both HCC1954 (C) and MDA-MB-231 (D) cell lines. Postimmune antibodies inhibited growth of ZR-75-1 cells (E) but did not affect viability of MCF-7 cells (F). Means \pm SDs of paired differences in cell-line viability are shown in the upper left of panels C, D, E, and F, and are in percentage-point units; paired $t$-test $P$ values appear immediately below the viability means \pm SDs. Mean fluorescence intensities (MFIs) of all subjects' pre- and postimmune plasma antibodies binding to MCF-7 (G) and ZR-75-1 (H) cells are shown. Bar heights \pm error bars in panels G, H denote the means \pm SDs of MFI; paired $t$-test $P$ values for the pre-post difference among all 6 subjects appear after the bar labels. (I) Purified IgG fraction of postimmune plasma derived from subject \#5 significantly inhibits growth of both HCC1954 and MDA-MB-231 cell lines. Bar heights \pm error bars denote the means \pm SEM of viability from three experiments with material from subject $\# 5$. 


\begin{tabular}{lcc}
\hline Subject & Ley & GD2 \\
\hline 1 & 2 & 4 \\
2 & 4 & 8 \\
3 & 8 & 4 \\
4 & 8 & 8 \\
5 & 4 & 4 \\
6 & 8 & 4 \\
\hline
\end{tabular}

Fold increase in endpoint titers relative to preimmune serum are shown.

cell lines. BR55-2 induced caspase-3/7 activation (Figure 4A) and growth inhibition in HCC1954 (Figure 4C, 4D) but not in MCF-7 cells (Figure 4B, 4C and 4D). The results with BR55-2 on the MCF-7 and HCC1954 cell lines parallel our observations testing functionality of P10sinduced serum antibodies on these cells (Figures 3C, 3F).

To further investigate the involvement of apoptosis and caspase 3 in immune-serum mediated inhibition of viability we tested subjects' serum against the ZR-75-1 cell line. ZR-75-1 is a slowly growing ER-positive cell

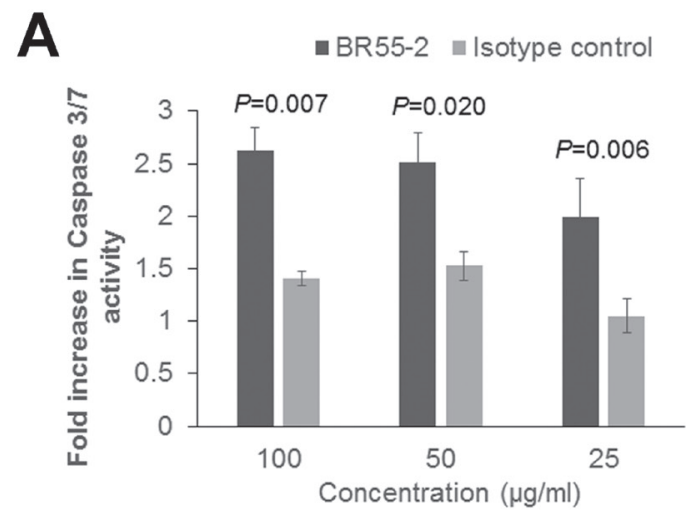

B

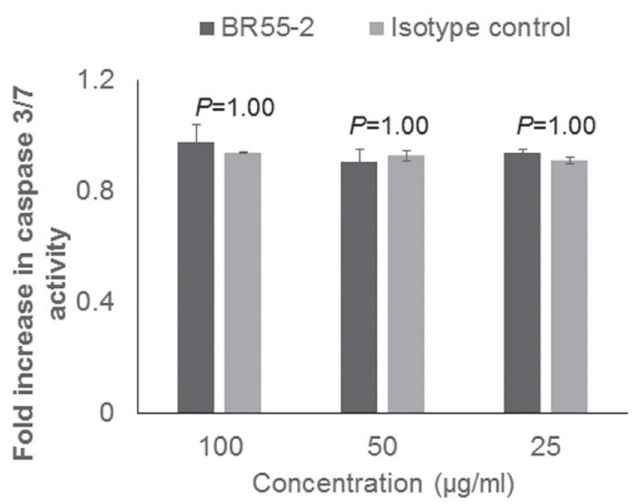

line similar to MCF-7, but expresses both a functional caspase 3 and LeY (Supplementary Figure 2D). Incubation of ZR-75-1 cells with postimmune serum led to annexin-V binding (Figure 5A) and upregulated caspase-3 expression levels (Figure 5B). Inhibition of caspase-3 activity in ZR$75-1$ cells in the presence of postimmune serum negated suppressive functionality of antibodies induced by the P10s-PADRE vaccine (Figure 5C).

Anti-GD2 monoclonal antibodies are also known to mediate caspase-3/7 cell killing [23]. As a further
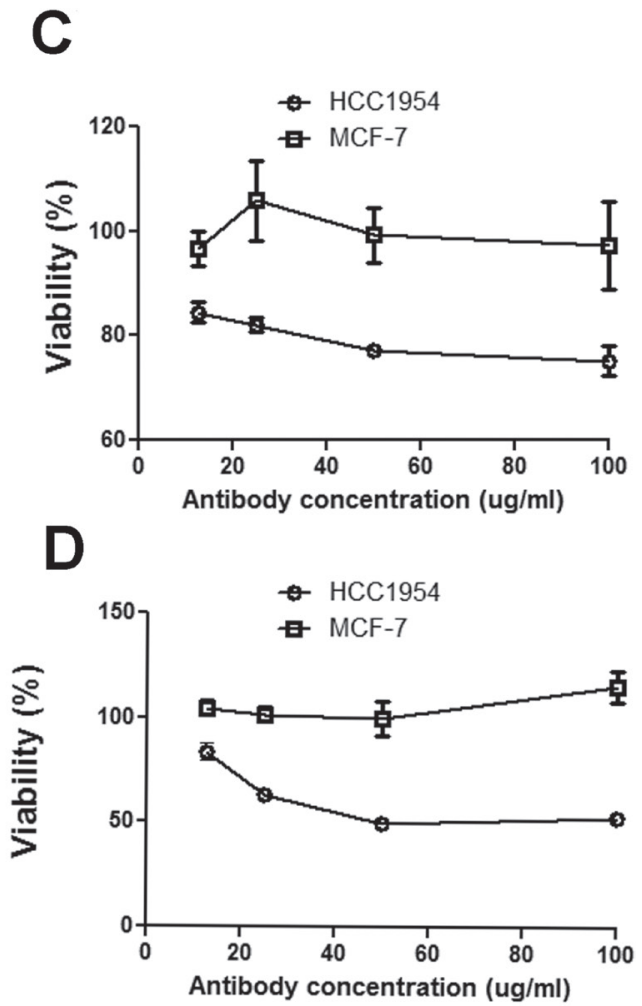

Figure 4: Anti-Lewis $Y$ monoclonal antibody BR55-2 induced caspase-3/7 activation and growth inhibition in HCC1954. HCC1954 (A) or MCF-7 (B) cells were incubated with various concentrations of BR55-2 and, after 24 hours of incubation, caspase-3 activity was measured. Two-way ANOVA with Bonferroni post-test was performed and $P$ values are shown. Bar heights \pm error bars denote means \pm SDs of three technical replicates. In separate experiments, the effect of BR55-2 on cell survival was measured after 24 (C) and 48 (D) hours of incubation using CCK-8 kit. Symbols \pm error bars at each tested antibody concentration denote means \pm SDs of three technical replicates. BR55-2 negatively affected viability of HCC1954 cells at all concentrations after 24 and 48 hours $(P<0.001)$, while no statistically significant growth inhibition was observed in MCF-7 cells $(P>0.05)$. 
positive control, caspase-3/7 activity was measured in MDA-MB-231 cells incubated with anti-GD2 mAb 3F8 and sera collected from immunized subjects. Incubation of MDA-MB-231 cells with immunized serum upregulated caspase-3 expression levels along with the anti-GD2 $\mathrm{mAb} 3 \mathrm{~F} 8$, but not with an isotype control antibody (Figure 6A). Abrogation of postimmune serum-induced apoptosis and growth inhibition of MDA-MB-231 cells by caspase-3 inhibitor further supports the conclusion that the proapoptotic functionality of antibodies induced by $\mathrm{P} 10 \mathrm{~s}$ depends on caspase-3 (Figures 6B, 6C).

\section{P10s-PADRE-induced immune serum was effective in 3D spheroid culture and sensitized spheroids to Paclitaxel treatment}

To examine the growth-inhibitory properties of the P10s-induced antibodies in a more relevant setting, spheroid cultures were formed, and the impact of pre- and postimmune serum alone and in combination with Paclitaxel on spheroid cultures of MDA-MB-231 and ZR-75-1 cells were detected (Figure 7). 3D-cultured cells that form dense multicellular spheroids may be better than 2D-cultured cells in simulating important tumor characteristics in vivo, namely hypoxia, dormancy, antiapoptotic features and their resulting drug resistance. We observed that postimmune serum disrupted spheroids of MDA-MB-231 cells and enhanced the effect of Paclitaxel treatment (Figure 7A). These results parallel our 2D studies with Docetaxel [37]. In ZR-75-1 cells the spheroids shrink in size upon combination of paclitaxel with immunized serum (Figure 7B) resulting in less viable cells (Figure 7C).

\section{DISCUSSION}

It is well known that TACA clustering or density has a substantial effect on recognition by antibodies [38, 39]
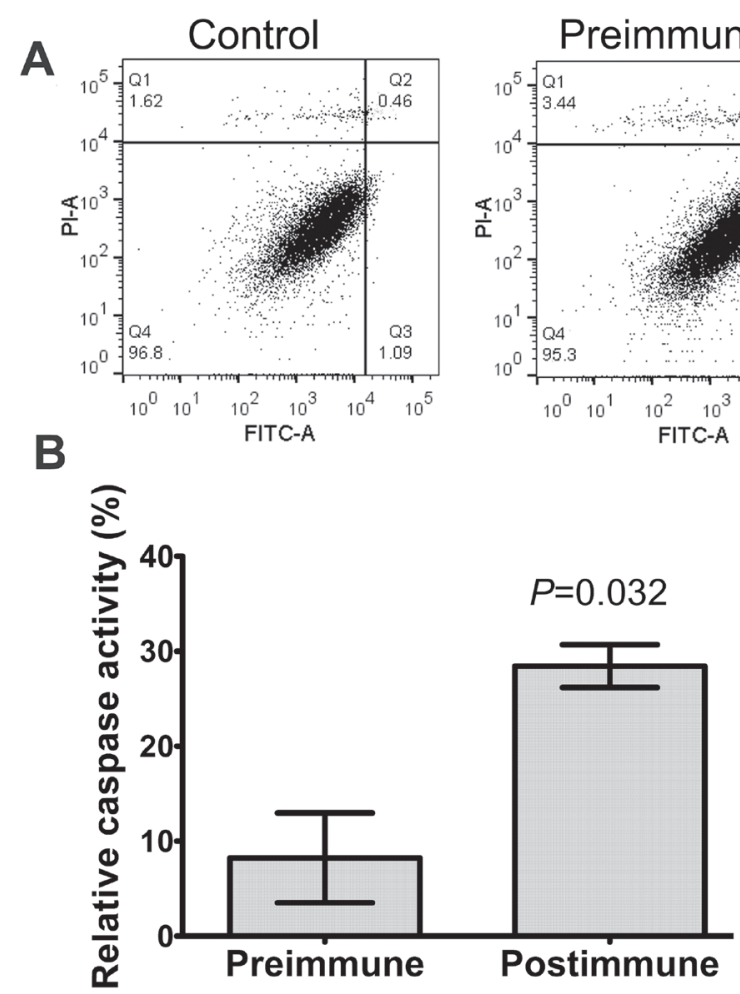
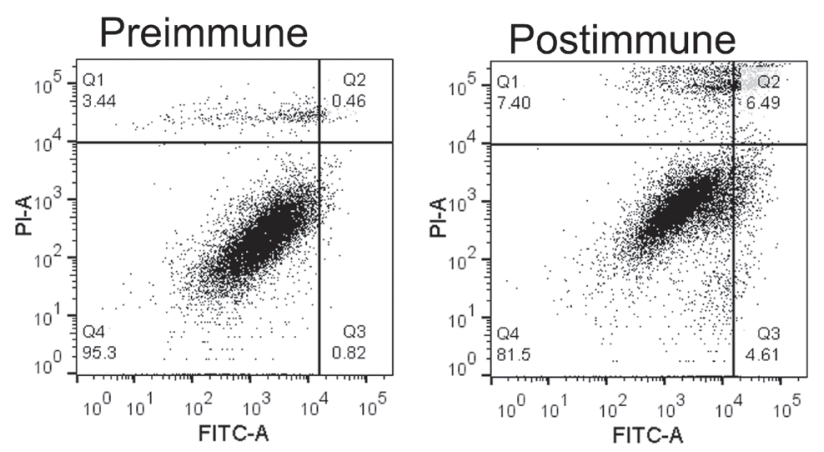

C

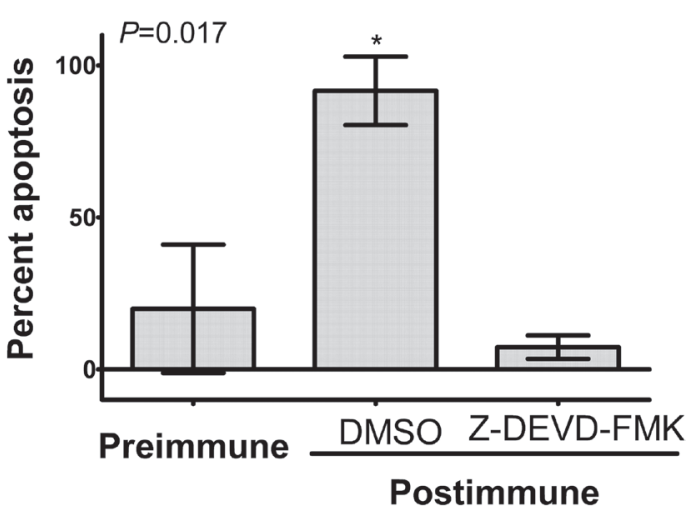

Figure 5: P10s-induced antibodies mediated apoptosis in ZR-75-1 with involvement of caspase 3. (A) Cells were incubated with 10\% FBS (control) or indicated sera overnight and then harvested and stained with annexin V-FITC (FL1) and propidium iodide (PI-A) using a live/dead assay kit from Invitrogen (Life Technologies, Grand Island, NY). Q3 and Q4 show apoptotic and necrotic cells, respectively . (B) ZR-75-1 cells were incubated with pre- and postimmune plasma overnight and then relative caspase-3 activity was measured as described in the procedure section. Bar heights \pm error bars represent means \pm SDs, which were compared by Student's $t$-test and the $P$ value is shown. These results are representative of two independent experiments. (C) ZR-75-1 cells were preincubated with Caspase-3 Inhibitor Z-DEVD-FMK or DMSO for 30 minutes and then pre- and postimmune plasma samples were added and incubation was continued overnight. Cells were then harvested and stained with Annexin-FITC. Relative positive cell percentage for each treatment was calculated based on cells treated with FBS. Bar heights \pm error bars represent means \pm SDs, which were compared by one-way ANOVA; the ANOVA $P$ value is shown. ", significantly different than preimmune and postimmune plus caspase-inhibitor at $P<0.05$ using Tukey's post-hoc procedure test. Apoptosis and caspase 3 activity in ZR-75-1 was performed using blood samples from patients 4 and 6 with similar results. The data for subject 6 is shown. 

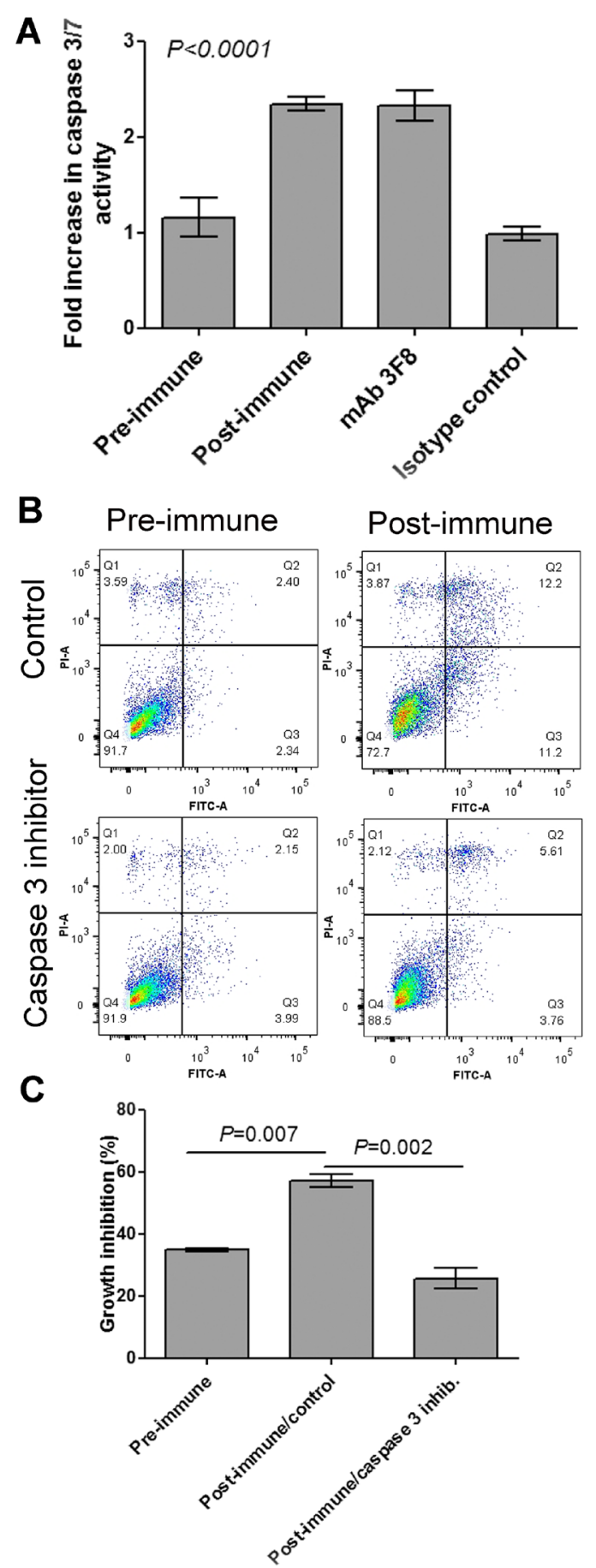

Figure 6: Caspase 3 is involved in post-immune serum-induced growth inhibition of MDA-MB-231 cells. (A) Cells were incubated with $10 \%$ FBS (control), indicated plasma samples, $3 \mathrm{~F} 8 \mathrm{mAb}$ or its isotype control for 48 hours and then caspase $3 / 7$ activity was measured. Bar heights and error bars show means and standard deviations, respectively, of three technical replications per treatment. One-way ANOVA with Bonferroni posttest was used to compare means. The $P$ value shows significance level comparing either Preimmune with postimmune or mAb with its isotype control. (B) MDA-MB-231 cells were preincubated with Caspase-3 Inhibitor Z-DEVD-FMK or DMSO (control) for 2 hours and then pre- and post-immune plasma were added and incubation continued overnight. Cells then were harvested and stained with annexin V-FITC (FL1) and propidium iodide (FL3) using a live/dead assay kit from Invitrogen (Life Technologies, Grand Island, NY). Q3 and Q4 show apoptotic and dead cells, respectively. (C) MDA-MB-231 cells were incubated with Pre- and postimmune plasma for 48 hours. Cells treaassigned to treatment with postimmune plasma were preincubated with Caspase-3 Inhibitor or control. Growth inhibition was calculated based on cells treated with FBS. Bar heights and error bars show means and standard deviations, respectively, of three technical replications per treatment. One-way ANOVA with Bonferroni posttest was performed, and resulting $P$ values are shown for post-immune/control compared to the other two treatments. Apoptosis and caspase 3 activity in MDAMB-231 was performed using blood samples from subject 6. 
and that the characteristics of carbohydrate epitopes on the surface of tumor cells is a governing factor for immune recognition and antibody-mediated targeting of tumorassociated carbohydrate antigens in cancer immunotherapy [40]. Likewise, density-dependent lectin-glycan interactions is a paradigm for conditional regulation by posttranslational modifications [41]. Antibodies reactive with TACAs are suggested to be selective for clustered TACA even in the presence of normal tissue $[9,35,42]$. Consequently, TACAs resulting either from restricted distribution on normal cell surface, incomplete synthesis or neosynthesis accumulate in high density or clustered configuration (possibly in novel conformations relative to glyans expressed on normal tissue) at the tumor cell surface selectively results in a lack of immune mediated tissue damage despite that antibodies can bind to "normal" tissue [9, 35].

Interfering with signaling mechanisms associated with TACA expression can stop the growth of tumors,
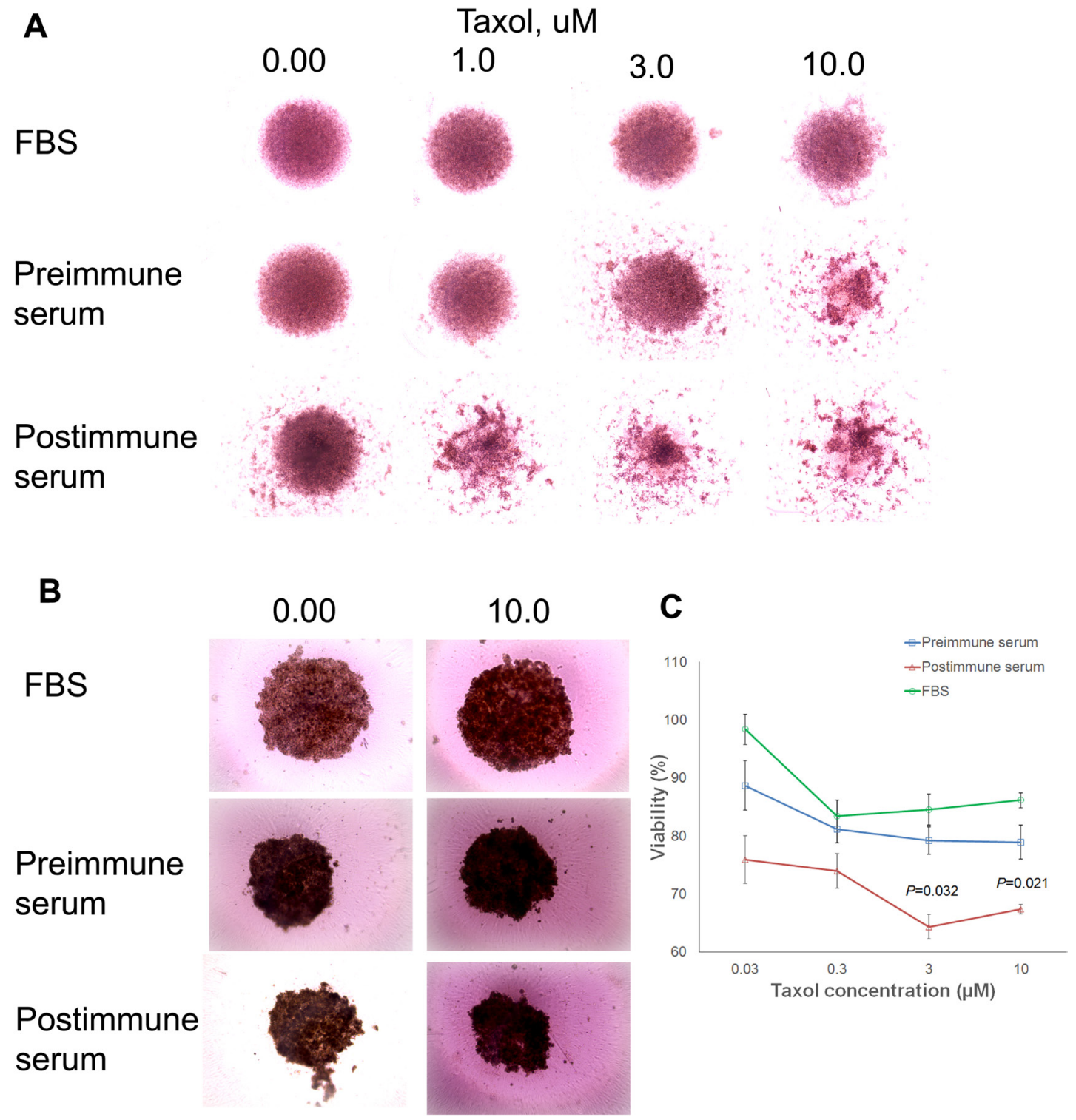

Figure 7: Immune serum enhancement of taxane effect. Preincubation of MDA-MB-231 (A) and ZR-75-1 (B) 3D culture with post-immune serum collected from subject 6 enhanced the effect of taxol on the spheroids. Cells were cultured in ultra-low adhesion roundbottom plates to force spheroid formation. 3000 cells were cultured in RPMI complete medium for 3 days. Pre- and post-immune sera then were added and cells were incubated for $24 \mathrm{~h}$, when fresh medium containing various concentrations of Taxol was added. After another two days of incubation, spheroids were photographed using EVOS ${ }^{\text {TM }}$ XL Core cell imaging system at 10x magnification. Adobe Photoshop then was used to compile individual images of various treatments in the figure as demonstrated. (C) At the end of the treatment period of ZR-75--1 cells, alamarBlue ${ }^{\circledR}$ assay was used to measure viability of cells in replicated wells, and percent viability was calculated relative to non-treated cells grown in normal medium supplemented with FBS. Symbols \pm error bars at each taxol concentration denote means \pm SDs of three technical replications. The experiment was repeated two times with similar results. $P$ values suggesting statistically significant differences between pre- and postimmune sera at 3 and $10 \mathrm{uM}$ concentrations of taxol are shown. 
and prevent the development of metastases [43]. TACAreactive antibodies are known to be proapoptotic both as monoclonal antibodies and as part of immune surveillance [44-46]. Both the LeY and ganglioside GD2 antigens can regulate signaling processes in several different ways that lends themselves to the progression of cancer [47-49]. Taking advantage of the polyspecific nature of antibodies, we developed P10s as a Pan-immunogen, reacting with multiple anti-TACA antibodies and lectins [45]. Therefore, the induction of polyreactive, proapoptotic antibodies would be a beneficial feature in cancer-immunotherapy approaches. The induction of such antibodies can provide for longer-term survival of cancer subjects, as such antibodies are clinically correlated with long-term survival [50]. Consequently, we developed P10s for clinical testing of vaccination of high-risk breast cancer subjects [9].

The vaccine was administered to subjects who met all eligibility criteria including the ability to mount a response to two recall antigens by skin testing. The rationale for this latter criterion was to select those subjects who have an active immune system capable of reacting to antigenic challenges. We employed a conservative 3 +3 dose-escalation design for this study, guided by the principle that this design is prudent when considering drugs that are associated with apoptosis [51, 52]. Six subjects met all criteria. All subjects enrolled on the study showed evidence of reactivity to the P10s-PADRE vaccine after immunization. We conclude that immunization with P10s-PADRE is feasible based on the high rate (100\%) of subjects who received all five immunizations on schedule.

$\mathrm{P} 10 \mathrm{~s}$ immunization induced antibodies reactive with P10s and specific for both LeY and GD2. No discernable binding was observed for the irrelevant a2-8 glycan. Assuming that anti-glycan antibodies in postimmune serum are of the same affinity as their corresponding monoclonal antibodies BR55-2 and 3F8, the concentration of anti-LeY and anti-GD2 antibodies is estimated as $1.8 \mu \mathrm{g} / \mathrm{ml}$ and $2.5 \mu \mathrm{g} / \mathrm{ml}$, respectively, of the total $\mathrm{IgG}$ fraction. Collectively, these data suggest that vaccination with P10s-PADRE induces a cross-reactive IgG response to both LeY and GD2 antigens as intended and demonstrating functional capability against tumor cells at relatively low single-digit $\mu \mathrm{g} / \mathrm{mL}$ serum antibody concentrations. Our results parallel our preclinical studies where we have shown that the induction of low titers of serum antibodies upon CMP immunization is sufficient to inhibit tumor growth in therapeutic and prophylactic murine tumor models [7, 8, 53].

Evaluation of the antibody response to P10s suggests that the $500 \mu \mathrm{g}$ dose may produce higher titers of anti-P10s IgG than the $300 \mu \mathrm{g}$ dose, although the small cohort sizes and lack of randomization preclude firmer conclusions regarding a dose effect. The titer analysis further suggests that only 3 immunizations are sufficient to generate an effective immune response with IgG titers sustained from week 7. Moreover, since no safety concerns were observed in subjects at the $500 \mu \mathrm{g}$ dose, but concerns exist about excessive adjuvant-related skin reaction with higher doses, it is deemed prudent to recommend $500 \mu \mathrm{g}$ per injection in future studies.

While P10s generated antibodies in all subjects, growth-inhibitory activity of postimmune antibodies was significantly higher than that of preimmune antibodies in 5 of the 6 subjects on three human breast cancer cell lines, with two of the cell lines considered representative of the extreme resistance to standard systemic therapy. MDAMB-231 cells are representative of basal-like carcinoma, whereas HCC1954 cells express HER2, but nonetheless have a de novo resistance to Trastuzumab. Moreover, for the 6 subjects as a whole, the average decrease in viability was statistically significant for both cell lines. Preimmune plasma from subject 5 displayed high levels of growth inhibition toward both cell lines. Testing the growth-inhibitory effect of purified IgG for this particular patient indicates a lack of involvement of $\mathrm{IgG}$ antibodies in the high background of crude preimmune plasma. This subject was treated with Faslodex ${ }^{\circledR}$ (Fulvestrant) two days before her preimmune blood draw. Fulvestrant is a selective ER down-regulator with a long half-life that can induce cell death in ER-positive breast cancer cells [54, 55]. Fulvestrant also inhibits growth of triple-negative breast cancer cell lines [56]. Therefore, the high growthinhibitory function of subject 5's preimmune plasma antibodies could be due to the residual effect of her drug treatment skewing the results

We observed some direct clinical benefit in one of our subjects with metastatic lesions as evaluated before and after vaccine treatment. This subject (39604) has been previously reported [37]. She had Her2-positive cancer with brain metastases, one of which was resected as part of her standard care; it was cystic and histologically negative for cancer. This subject has had progression including one additional brain metastasis (6 years after vaccine), but is alive and continuing standard therapy. A second subject (39616), also Her2-positive, achieved a complete response and is remaining in remission 4 years off of all therapy. A third patient (39609) has continued the same endocrine therapy with stable disease for 54 months post vaccine. A fourth subject (39608) progressed after 8 months, but is still alive and stable. We speculate that some degree of synergism might exist between the vaccineinduced antibodies and some systemic agents [37]. We observed that pre-incubation with postimmune serum enhanced paclitaxel-induced cell damage in 3D cultures. Multicellular tumor spheroids of cell lines mimic avascular tumor areas characterized by the establishment of diffusion gradients, reduced proliferation rates and increased drug resistance [57-59]. Manipulation of apoptosis has emerged as a new therapeutic strategy to eliminate cancer cells. Our results indicate that P10s-induced immune serum potentiates chemosensitivity to taxanes. Paclitaxel (Taxol) is known to arrest cells in mitosis through microtubule 
stabilization and to induce apoptosis $[60,61]$. Paclitaxel is found to exhibit cytotoxic and antitumor activity by inducing apoptosis via caspase-3 activation [62, 63]. Some studies suggest that GD2-specific monoclonal antibodies induce apoptosis and enhance cytotoxicity of chemotherapeutic drugs [33]. GD2 ganglioside-specific antibody treatment downregulates the PI3K/Akt/mTOR signaling network [22]. Likewise, the LeY antigen increases tumor cell drug resistance $[64,65]$. An indepth understanding of signaling transduction pathways that overcome chemotherapy resistance will provide a basis for increasing chemosensitivity and developing new chemotherapies.

The evidence in this study serves as a proof of principle for immunization using P10s-PADRE to induce antibodies that are proapoptotic against human breast cancer cells. While not a study endpoint, it is worth noting that the overall survival among the subjects treated with the P10s vaccine had a mean \pm SE of $52 \pm$ 9 months (median not reached). A randomized clinical trial is required to assess the efficacy of P10s in treating this patient population. It also speaks to the idea of other means of targeting TACA expressing tumor cells. CAR-T cells, for example, have been developed to target glycoforms of MUC1 [66] and against the Chondroitin sulfate proteoglycan isoforms [67]. CAR-T cells have been developed against GD2 [68-70] and LeY [71, 72]. Consequently, multiple immunotherapy approaches targeting TACAs may finally find their way to clinical success.

\section{MATERIALS AND METHODS}

\section{Experimental design}

\section{Study design}

Between July 2011 and December 2013, we conducted a Phase I dose-escalation trial to assess the safety and tolerability of the CMP vaccine, P10s-PADRE, in subjects with Stage IV breast cancer. This trial utilized the conventional $3+3$ cohort design for dose-escalation studies [73], was approved by the Institutional Review Board (IRB) of the University of Arkansas for Medical Sciences (UAMS), and was registered with the NIH clinical-trials registry at http://clinicaltrials.gov. Women 18 years of age or older, of all races, with histologically or cytologically confirmed stage IV breast cancer were eligible, and subjects were enrolled after providing written informed consent. Disease staging was done according to the American Joint Commission on Cancer (AJCC), sixth edition.

The following eligibility criteria were used: The cancer may be newly diagnosed metastatic or relapsed after primary or adjuvant therapy, and must not have required a treatment change for 2 months. Treatments with anti-estrogen therapy or chemotherapy were allowed. The chemotherapy regimen could not contain steroids in the pre- or post-supportive-care medications. Additional eligibility criteria included: an Eastern Cooperative Oncology Group performance status of 0-1 and adequate organ function (white blood cell count $\geq$ $3,000 / \mathrm{mm}^{3}$, hemoglobin $\geq 8.0 \mathrm{~g} / \mathrm{dL}$, platelets $\geq 100,000 /$ $\mathrm{mm}^{3}$ within 2 weeks prior to registration, total bilirubin $\leq 3.0 \mathrm{mg} / \mathrm{dL}$, aspartate aminotransferase $\leq 200 \mathrm{IU} / \mathrm{L}$, alanine aminotransferase $\leq 200 \mathrm{IU} / \mathrm{L}$, and serum creatinine $\leq 1.5 \mathrm{mg} / \mathrm{dL}$ ). Subjects had to be immunocompetent as measured by responsiveness to skin-test challenges with recall antigens from Trichophyton and Candida.

The following exclusion criteria were applied: known brain metastasis; pregnancy or lactation; known history of HIV infection; clinically serious infection; severe cardiac insufficiency; other active malignancy; history of organ allograft; immunodeficiency or history of splenectomy; concurrent treatment with steroids or immunosuppressive agents; and unsuitability for the trial, based on clinical judgment.

\section{Vaccine preparation and immunization schedule}

P10s (WRYTAPVHLGDG) was covalently attached to the Pan-T-cell peptide PADRE (dAKchAVAAWTLKAAdA: AmbioPharm, Inc., North Augusta, SC, USA). The peptide vaccine was administered in liquid form, emulsified with the adjuvant Montanide ISA-51VG, (SEPPIC, Inc., Fairfield, NJ, USA), by subcutaneous (SC) injections on 5 separate occasions during Weeks 1, 2, 3, 7, and 19. The peptide was synthesized according to Good Manufacturing Practice guidelines.

\section{Treatment schema}

Subjects were treated in groups of three, the first at the initial dose of $300 \mu \mathrm{g}$ P10s-PADRE per injection. If there were no dose-limiting toxicities (DLTs) in this first group, we planned to escalate to the final dose of $500 \mu \mathrm{g}$ P10s-PADRE per injection, and treat the next group at this final dose. If there were two or three DLTs in the first group, we planned to de-escalate to a safety dose of $100 \mu \mathrm{g}$ per injection, and treat three subjects at this safety dose. If there were exactly one DLT in the first group, we planned to vaccinate three more subjects at the initial dose, and escalate to the final dose only if no additional DLTs were observed. All subjects were included in the safety assessment.

\section{Endpoint variables}

Assessment of safety was the primary endpoint. The secondary endpoints were anti-P10s antibody titers, antibody binding to breast cancer cells, and toxicity towards breast cancer cells. 


\section{Adverse event monitoring}

Adverse events were assessed using the NCI Common Terminology Criteria for Adverse Events (CTCAE), Version 4.0.

\section{ELISA assay and IgG purification}

ELISA was used to determine the titer of antiP10s antibodies in the serum and plasma of subjects before and after vaccination as described earlier [37]. The anti-P10s-MAP endpoint titers were estimated from absorbance-versus-dilution curves by linear regression as previously described [37]. Briefly, the intercept of the regression line for each subject's preimmune serum was the value used as the absorbance cutoff for determining end-point titer for that subject, and the dilution where each sample's regression line crossed the subject's absorbance cutoff was defined to be the sample's endpoint titer. Extrapolation beyond one dilution below the minimum or above the maximum actual dilutions was not allowed.

To assess binding of vaccine-induced antibodies to GD2 or LeY, plates were coated with ganglioside GD2 (3 $\mu \mathrm{g} / \mathrm{ml}$, Sigma- Aldrich, Saint Louis, MO) or LeY-PAA (Glycotech, Gaithersburg, MD). After blocking, sera were added and incubated for $2 \mathrm{~h}$ at $37^{\circ} \mathrm{C}$ and then after washing, the wells were incubated with goat anti-human IgG (Sigma-Aldrich) for $1 \mathrm{~h}$ at $37^{\circ} \mathrm{C}$. Binding was visualized and plates were read using an ELISA reader at $450 \mathrm{nM}$. To determine anti-glycan endpoint titers, the mean background (preimmune) absorbance plus 3 standard deviations was used as the cutoff absorbance. Then, mean absorbance was calculated from duplicates for pre- and postimmune serum dilution, and the highest dilution with an absorbance above the cutoff absorbance was used to determine the endpoint titer. The fold change in endpoint titer was then calculated by dividing the endpoint titer for postimmune to the endpoint titer for preimmune sera [9]. IgG fraction of pre- and post-immune plasma or sera was enriched using $\mathrm{Nab}^{\mathrm{TM}}$ Protein G Spin Kit and Zeba ${ }^{\mathrm{TM}}$ desalting columns (Thermo Scientific, Rockford, IL). Anti-GD2 and $-\mathrm{LeY}$ reactivity of purified $\mathrm{IgG}$ was examined by ELISA as described above. Serum concentrations of anti-LeY and anti-GD2 antibodies were determined from binding-curve shifts. Briefly, binding-curve shifts were calculated from the log-log plots of amount of bound antibodies vs immunoglobulin concentration by minimizing the mean square difference between the control curve $(\mathrm{mAb})$ and the theoretical test curve using the slope and intercept of each theoretical curve (serum IgG) and concentration values corrected by the shift value. The calculation and optimization were done in Excel using Solver.

\section{Cell lines, tissue culture and MAbs}

Human breast cancer cell lines were purchased from ATCC (Manassas, VA) and most cell experiments were performed within 6 months after their receipt. However, after the completion of experiments outlined in this paper, the identity of all cell lines used in this study was confirmed by the Human Cell Line Authentication test (Genetica DNA Laboratories, Burlington, NC). Cells were cultured in a base medium supplemented with $10 \%$ heatinactivated fetal bovine serum (Life Technologies), 50 units $/ \mathrm{mL}$ penicillin, and $50 \mu \mathrm{g} / \mathrm{mL}$ streptomycin. The base medium for MDA-MB-231 was DMEM, for HCC1954 was RPMI, and for MCF-7 cells was insulin-supplemented MEM (all from Fisher Scientific, Pittsburgh, PA). MCF$10 \mathrm{~A}$ cells were grown in MEGM complete medium (Lonza, Basel, Switzerland) that was replaced by RPMI containing $10 \%$ FBS 24 hours prior to treatment with blood samples. Serum, plasma, purified IgG or mAbs were used to treat cells. MAbs used in our studies include the LeY reactive MAb BR55-2 (a gift from Zenon Steplewski [74]), 14G2a (BD Biosciences, San Jose, CA ) and 3F8 (a gift from Dr. Ni-Kong V. Cheung, Memorial Sloan Kettering Cancer Center, New York, NY).

\section{Flow cytometry}

Binding of serum or plasma antibodies to breast cancer cell lines was determined as described earlier [37]. Briefly, cells were harvested with an enzyme-free celldissociation buffer (Life Technolgies, Grand Island, NY), washed with flow-cytometry buffer (PBS containing 1\% BSA and $0.1 \%$ sodium azide) and incubated with preimmune and post-immune samples or mAbs in the same buffer. Binding was visualized with a FITC-conjugated goat anti-human (BD Biosciences, San Jose, CA) or mouse IgG (Sigma-Aldrich).

\section{Tumor-cell growth-inhibition and cell-toxicity assays}

The functional effect of immunized blood samples against breast cancer cell lines was performed by cell toxicity and growth inhibition assays. The cytotoxicity was assayed as previously described [37]. Briefly, $5 \times 10^{4}$ (24-well plate) cells were seeded in medium containing $10 \%$ FBS. After 24 hours of incubation, the medium was refreshed with media containing $10 \%$ preimmune or postimmune serum or plasma, based on availability, as indicated in the figure legends. The medium in control wells contained $10 \%$ FBS. Twenty-four hours after addition of blood samples, supernatants were removed, and live cells were fixed, stained with Crystal violet, and counted. Percent viability was calculated as the percentage of cells surviving in the treated wells relative to the cells in control wells. Cell Counting Kit-8 (CCK-8, Dojindo 
Molecular Tech. Gaithersburg, MD) was also used to measure viability. All samples were assayed in triplicate. Images were taken using EVOS ${ }^{\text {TM }}$ XL Core cell imaging system (Thermo Fisher Scientific, Waltham, MA) at 10X magnification.

The growth-inhibitory role of serum antibodies against MDA-MB-231 and ZR-75-1 cells was assayed in a 3-D culture. 3000 cells were seeded in Corning ${ }^{\circledR}$ roundbottom ultra-low attachment 96-well plates (Corning Inc., Lowell, MA) and were allowed to grow for 2 to 3 days to generate spheroids. Pre- and postimmune sera were then added into wells as described above. The cells were left to grow for 24 hours when the medium was refreshed using medium containing various concentrations of Taxol. Cells were then left to grow for another 48 hours, after which pictures were taken and viability was determined using alamarBlue ${ }^{\circledR}$ cell viability assay (Thermo Fisher Scientific Inc., Waltham, MI) according to the manufacturer's instructions. Fluorescence intensity was measured (Microplate Fluorescence Reader (Bio-Tek Instruments, Winooski, VT) and percent viability relative to the wells with FBS was quantified. Images were taken using EVOS ${ }^{\mathrm{TM}} \mathrm{XL}$ Core cell imaging system at $10 \mathrm{X}$ magnification.

\section{Apoptosis assay and Caspase-3 activity}

Apoptosis was determined using FITC-conjugated Annexin V (Life Technologies, Grand Island, NY) by flow cytometry as described earlier [37]. Caspase-3 activity was measured using Apo-ONE ${ }^{\circledR}$ Homogeneous Caspase-3/7 Assay (Promega, Madison, WI), following manufacturer's instructions. Briefly, cells were seeded in wells $\left(1 \times 10^{4}\right.$ cells/ well $)$ of a 96 -well plate in complete media overnight. Media were replaced the next day with media supplemented with $10 \%$ of either FBS (control), preimmune, or postimmune serum or plasma. Alternatively, mAbs were added in medium containing $5 \% \mathrm{FBS}$. Cells were incubated at $37^{\circ} \mathrm{C}$ for an additional 8 to 48 hours, then Apo-ONE ${ }^{\circledR}$ Caspase-3/7 Reagent was added to wells in a $1: 1$-volume ratio. Plates were then gently shaken at $500 \mathrm{rpm}$ for $1 \mathrm{~min}$ and incubated at room temperature for 1-2 hours. Caspase activity was quantified using a fluorescence reader with a 490-nm excitation filter and 520-nm emission filter.

To inhibit caspase activity in the presence of serum or plasma samples, cells were seeded in complete medium, and after overnight culture, supernatant was removed and replaced with serum-free medium. The caspase-3 inhibitor Z-DEVD-FMK (R\&D Systems, Minneapolis, $\mathrm{MN}$ ) was added to wells at a final concentration of $50 \mu \mathrm{m} / \mathrm{ml}$. Z-DEVD-FMK is an effective irreversible caspase inhibitor with no cytotoxic effects. DMSO was added to the control wells. Cells were incubated with caspase inhibitor at $37^{\circ} \mathrm{C}$ for 2 hours, then preimmune and postimmune samples were added, and the incubation continued.

\section{Statistical assessments}

The resulting absorbance-versus-dilution curves derived from anti-peptide ELISA assays were used to estimate normalized endpoint titers as previously described [37]. SAS 9.3 (The SAS Institute, Cary, NC) was used to calculate the endpoint titers of anti-P10s antibodies and analyze them for changes with respect to time, dose cohort, and their interaction using the nonparametric repeated-measures method of Brunner et al. [75] and in particular, using the recommended ANOVA-type statistics from this method. Excel 2010 (Microsoft Corporation, Redmond, WA) was used to evaluate the effect of vaccination on plasma cytotoxicity towards cell lines by one-sample $t$-test on paired differences. To compare the binding of purified IgG fraction of pre and postimmune sera to the peptide and carbohydrates, the slopes of the dilution curves were calculated and compared using regression analysis performed by GraphPad Prism version 5.00 for Windows (GraphPad Software, San Diego, CA).

\section{CONCLUSIONS}

This early-phase clinical trial of a CMP vaccine shows that immunization is feasible and safe, and that immunization with P10s-PADRE vaccine induces a potentially beneficial immunologic response with the induction of proapoptotic antibodies.

\section{Ethics approval and consent to participate}

The clinical trial and all procedure were approved by the UAMS IRB (reference number 110396), and registered with the NIH clinical-trials registry at http:// clinicaltrials.gov (NCT01390064). Informed consent was obtained from all individuals included in the study.

\section{Consent for publication}

Not applicable.

\section{Availability of data and materials}

The data generated and analyzed during the current study are available from the corresponding author on reasonable requests.

\section{Abbreviations}

ANOVA, analysis of variance; CMP, carbohydrate mimicking peptide; DLT, dose-limiting toxicities; GD2, ganglioside disialic 2; GM2 and GM3, ganglioside monosialic 2 and 3; HER2, Her2/neu proto-oncogene neu; IgG, immunoglobulin G; IgM, immunoglobulin ; IRB, Institutional Review Board; LeY, Lewis Y antigen; mAb, monoclonal antibody; PADRE, pan DR T helper epitope; 
SC, subcutaneous; SE, standard error; TACA, tumor associated carbohydrate antigens; UAMS, University of Arkansas for Medical Sciences.

\section{Author contributions}

L.F.H., I.M., E.R.S., B.M-K. and T.K-E. designed the early-phase study. E.R.S., Anastas P., and B.M-K. conducted statistical analyses of the results. F.J., X. G. and B.M-K., conducted the laboratory experiments. L.F.H., I.M., Angela P., and P.D.E., conducted the clinical trial, and all authors contributed to the writing of the manuscript.

\section{ACKNOWLEDGMENTS}

We thank Dr. Nai Kong Cheung of Memorial Sloan Kettering for supplying us with the mAb 3F8 and Dr. Zenon Steplewski for mAb BR55-2.

\section{CONFLICTS OF INTEREST}

TKE and BMK are named as inventors on an institutional patent application filled by UAMS that is related to the content of this manuscript. Therefore, Drs. Kieber-Emmons, Monzavi-Karbassi, and UAMS have a potential financial interest in the vaccine used in this clinical trial. No financial or other support of any kind has resulted from this patent application. These financial interests have been reviewed and the clinical trial was performed by approved supervision in accordance with the UAMS conflict of interest policies. The other authors declare that they have no competing interests.

\section{FUNDING}

This work was supported by a Clinical Translational Award from the Department of Defense Breast Cancer Program (W81XWH-06-1-0542) to TKE. Also supported by the UAMS Translational Research Institute (TRI), UL1TR000039 through the NIH National Center for Research Resources and National Center for Advancing Translational Sciences and the UAMS Center for Microbial Pathogenesis and Host Inflammatory Responses, P20 GM103625. The content is solely the responsibility of the authors and does not necessarily represent the official views of the NIH or UAMS.

\section{REFERENCES}

1. Hakomori S. Glycosylation defining cancer malignancy: new wine in an old bottle. Proc Natl Acad Sci U S A. 2002; 99:10231-10233.

2. Smaletz O, Diz MD, do Carmo CC, Sabbaga J, CunhaJunior GF, Azevedo SJ, Maluf FC, Barrios CH, Costa
RL, Fontana AG, Madrigal V, Wainstein AJ, Yeda FP, et al. A phase II trial with anti-Lewis-Y monoclonal antibody (hu3S193) for the treatment of platinum resistant/ refractory ovarian, fallopian tube and primary peritoneal carcinoma. Gynecol Oncol. 2015; 138:272-277. https://doi. org/210.1016/j.ygyno.2015.1005.1023.

3. Perez Horta Z, Goldberg JL, Sondel PM. Anti-GD2 $\mathrm{mAbs}$ and next-generation $\mathrm{mAb}$-based agents for cancer therapy. Immunotherapy. 2016; 8:1097-1117. https://doi. org/1010.2217/imt-2016-0021.

4. Qiu L, Li J, Yu S, Wang Q, Li Y, Hu Z, Wu Q, Guo Z, Zhang J. A novel cancer immunotherapy based on the combination of a synthetic carbohydrate-pulsed dendritic cell vaccine and glycoengineered cancer cells. Oncotarget. 2015; 6:5195-5203. https://doi.org/10.18632/ oncotarget.2908.

5. Ragupathi G, Koide F, Livingston PO, Cho YS, Endo A, Wan Q, Spassova MK, Keding SJ, Allen J, Ouerfelli O, Wilson RM, Danishefsky SJ. Preparation and evaluation of unimolecular pentavalent and hexavalent antigenic constructs targeting prostate and breast cancer: a synthetic route to anticancer vaccine candidates. J Am Chem Soc. 2006; 128:2715-2725.

6. Song C, Zheng XJ, Liu CC, Zhou Y, Ye XS. A cancer vaccine based on fluorine-modified sialyl-Tn induces robust immune responses in a murine model. Oncotarget. 2017; 8:47330-47343. https://doi.org/10.18632/oncotarget.17646.

7. Kieber-Emmons T, Luo P, Qiu J, Chang TY, O I, BlaszczykThurin M, Steplewski Z. Vaccination with carbohydrate peptide mimotopes promotes anti-tumor responses. Nat Biotechnol. 1999; 17:660-665.

8. Monzavi-Karbassi B, Artaud C, Jousheghany F, Hennings L, Carcel-Trullols J, Shaaf S, Korourian S, Kieber-Emmons $\mathrm{T}$. Reduction of spontaneous metastases through induction of carbohydrate cross-reactive apoptotic antibodies. J Immunol. 2005; 174:7057-7065.

9. Monzavi-Karbassi B, Hennings LJ, Artaud C, Liu T, Jousheghany F, Pashov A, Murali R, Hutchins LF, KieberEmmons T. Preclinical studies of carbohydrate mimetic peptide vaccines for breast cancer and melanoma. Vaccine. 2007; 25:3022-3031.

10. Monzavi-Karbassi B, Luo P, Jousheghany F, TorresQuinones M, Cunto-Amesty G, Artaud C, KieberEmmons T. A mimic of tumor rejection antigen-associated carbohydrates mediates an antitumor cellular response. Cancer Res. 2004; 64:2162-2166.

11. Wondimu A, Zhang T, Kieber-Emmons T, Gimotty P, Sproesser K, Somasundaram R, Ferrone S, Tsao CY, Herlyn D. Peptides mimicking GD2 ganglioside elicit cellular, humoral and tumor-protective immune responses in mice. Cancer Immunol Immunother. 2008; 57:1079-1089.

12. Luo P, Canziani G, Cunto-Amesty G, Kieber-Emmons T. A molecular basis for functional peptide mimicry of a carbohydrate antigen. J Biol Chem. 2000; 275:1614616154. 
13. Qiu J, Luo P, Wasmund K, Steplewski Z, Kieber-Emmons T. Towards the development of peptide mimotopes of carbohydrate antigens as cancer vaccines. Hybridoma. 1999; 18:103-112.

14. Sakamoto J, Furukawa K, Cordon-Cardo C, Yin BW, Rettig WJ, Oettgen HF, Old LJ, Lloyd KO. Expression of Lewisa, Lewisb, $\mathrm{X}$, and $\mathrm{Y}$ blood group antigens in human colonic tumors and normal tissue and in human tumor-derived cell lines. Cancer Res. 1986; 46:1553-1561.

15. Miyake M, Taki T, Hitomi S, Hakomori S. Correlation of expression of $\mathrm{H} / \mathrm{Le}(\mathrm{y}) / \mathrm{Le}(\mathrm{b})$ antigens with survival in patients with carcinoma of the lung. N Engl J Med. 1992; 327:14-18.

16. Yin BW, Finstad CL, Kitamura K, Federici MG, Welshinger M, Kudryashov V, Hoskins WJ, Welt S, Lloyd KO. Serological and immunochemical analysis of Lewis y (Ley) blood group antigen expression in epithelial ovarian cancer. Int J Cancer. 1996; 65:406-412.

17. Zhang S, Zhang HS, Cordon-Cardo C, Reuter VE, Singhal AK, Lloyd KO, Livingston PO. Selection of tumor antigens as targets for immune attack using immunohistochemistry: II. Blood group-related antigens. Int J Cancer. 1997; 73:50-56.

18. Madjd Z, Parsons T, Watson NF, Spendlove I, Ellis I, Durrant LG. High expression of Lewis $y / b$ antigens is associated with decreased survival in lymph node negative breast carcinomas. Breast Cancer Res. 2005; 7:R780-787.

19. Klinger M, Farhan H, Just H, Drobny H, Himmler G, Loibner H, Mudde GC, Freissmuth M, Sexl V. Antibodies directed against Lewis-Y antigen inhibit signaling of Lewis-Y modified ErbB receptors. Cancer Res. 2004; 64:1087-1093.

20. Liu J, Lin B, Hao Y, Qi Y, Zhu L, Li F, Liu D, Cong J, Zhang $\mathrm{S}$, Iwamori M. Lewis y antigen promotes the proliferation of ovarian carcinoma-derived RMG-I cells through the PI3K/Akt signaling pathway. J Exp Clin Cancer Res. 2009; 28:154. https://doi.org/10.1186/1756-9966-1128-1154.

21. Gao J, Hu Z, Liu J, Liu D, Wang Y, Cai M, Zhang D, Tan M, Lin B. Expression of CD147 and Lewis y antigen in ovarian cancer and their relationship to drug resistance. Med Oncol. 2014; 31:920. https://doi.org/910.1007/s1203212014-10920-12039.

22. Durbas M, Horwacik I, Boratyn E, Kamycka E, Rokita H. GD2 ganglioside specific antibody treatment downregulates $\mathrm{PI}$ K/Akt/mTOR signaling network in human neuroblastoma cell lines. Int J Oncol. 2015; 47:1143-1159. https://doi. org/1110.3892/ijo.2015.3070.

23. Tsao CY, Sabbatino F, Cheung NV, Hsu JC, Villani V, Wang X, Ferrone S. Anti-proliferative and pro-apoptotic activity of GD2 ganglioside-specific monoclonal antibody 3F8 in human melanoma cells. Oncoimmunology. 2015; 4:e1023975.

24. Cheever MA, Allison JP, Ferris AS, Finn OJ, Hastings BM, Hecht TT, Mellman I, Prindiville SA, Viner JL, Weiner LM, Matrisian LM. The prioritization of cancer antigens: a national cancer institute pilot project for the acceleration of translational research. Clin Cancer Res. 2009; 15:5323-5337. https://doi.org/5310.1158/1078-0432.CCR-5309-0737.

25. Liang YJ, Ding Y, Levery SB, Lobaton M, Handa K, Hakomori SI. Differential expression profiles of glycosphingolipids in human breast cancer stem cells vs. cancer non-stem cells. Proc Natl Acad Sci U S A. 2013; 110:4968-4973. https://doi.org/4910.1073/pnas.1302825110.

26. Battula VL, Shi Y, Evans KW, Wang RY, Spaeth EL, Jacamo RO, Guerra R, Sahin AA, Marini FC, Hortobagyi G, Mani SA, Andreeff M. Ganglioside GD2 identifies breast cancer stem cells and promotes tumorigenesis. J Clin Invest. 2012; 122:2066-2078. https://doi.org/2010.1172/JCI59735.

27. De Giorgi U, Cohen EN, Gao H, Mego M, Lee BN, Lodhi A, Cristofanilli M, Lucci A, Reuben JM. Mesenchymal stem cells expressing GD2 and CD271 correlate with breast cancer-initiating cells in bone marrow. Cancer Biol Ther. 2011; 11:812-815.

28. Cazet A, Bobowski M, Rombouts Y, Lefebvre J, Steenackers A, Popa I, Guerardel Y, Le Bourhis X, Tulasne D, Delannoy $P$. The ganglioside $G(D 2)$ induces the constitutive activation of c-Met in MDA-MB-231 breast cancer cells expressing the G(D3) synthase. Glycobiology. 2012; 22:806-816. https:// doi.org/810.1093/glycob/cws1049.

29. Groux-Degroote S, Guerardel Y, Julien S, Delannoy P. Gangliosides in Breast Cancer: New Perspectives. Biochemistry (Mosc). 2015; 80:808-819. https://doi. org/810.1134/S0006297915070020.

30. Orsi G, Barbolini M, Ficarra G, Tazzioli G, Manni P, Petrachi T, Mastrolia I, Orvieto E, Spano C, Prapa M, Kaleci S, D'Amico R, Guarneri V, et al. GD2 expression in breast cancer. Oncotarget. 2017; 8:31592-31600. https:// doi.org/31510.18632/oncotarget.16363.

31. Wiesner DA, Sweeley CC. Circulating gangliosides of breast-cancer patients. Int J Cancer. 1995; 60:294-299.

32. Aziz F, Qiu Y. The role of anti-LeY antibody in the downregulation of MAPKs/COX-2 pathway in gastric cancer. Curr Drug Targets. 2014; 15:469-476.

33. Kowalczyk A, Gil M, Horwacik I, Odrowaz Z, Kozbor D, Rokita H. The GD2-specific 14G2a monoclonal antibody induces apoptosis and enhances cytotoxicity of chemotherapeutic drugs in IMR-32 human neuroblastoma cells. Cancer Lett. 2009; 281:171-182. https://doi. org/110.1016/j.canlet.2009.1002.1040.

34. Cazet A, Julien S, Bobowski M, Burchell J, Delannoy P. Tumour-associated carbohydrate antigens in breast cancer. Breast Cancer Res. 2010; 12:204. https://doi.org/210.1186/ bcr2577.

35. Hennings L, Artaud C, Jousheghany F, Monzavi-Karbassi B, Pashov A, Kieber-Emmons T. Carbohydrate mimetic peptides augment carbohydrate-reactive immune responses in the absence of immune pathology. Cancers (Basel). 2011; 3:4151-4169. https://doi.org/4110.3390/cancers3044151.

36. Blanc C, Deveraux QL, Krajewski S, Janicke RU, Porter AG, Reed JC, Jaggi R, Marti A. Caspase-3 is essential for procaspase-9 processing and cisplatin-induced apoptosis of MCF-7 breast cancer cells. Cancer Res. 2000; 60:4386-4390. 
37. Makhoul I, Hutchins L, Emanuel PD, Pennisi A, Siegel E, Jousheghany F, Monzavi-Karbassi B, Kieber-Emmons T. Moving a Carbohydrate Mimetic Peptide into the clinic. Hum Vaccin Immunother. 2015; 11:37-44. https://doi. org/10.4161/hv.34300.

38. Nores GA, Dohi T, Taniguchi M, Hakomori S. Densitydependent recognition of cell surface GM3 by a certain anti-melanoma antibody, and GM3 lactone as a possible immunogen: requirements for tumor-associated antigen and immunogen. J Immunol. 1987; 139:3171-3176.

39. Zhang Y, Campbell C, Li Q, Gildersleeve JC. Multidimensional glycan arrays for enhanced antibody profiling. Mol Biosyst. 2010; 6:1583-1591. https://doi. org/1510.1039/c002259d.

40. Ravindranath MH, Bauer PM, Cornillez-Ty C, Garcia J, Morton DL. Quantitation of the density of cell surface carbohydrate antigens on cancer cells with a sensitive cellsuspension ELISA. J Immunol Methods. 1996; 197:51-67.

41. Dennis JW, Brewer CF. Density-dependent lectin-glycan interactions as a paradigm for conditional regulation by posttranslational modifications. Mol Cell Proteomics. 2013; 12:913-920. https://doi.org/910.1074/mcp.R1112.026989.

42. Hakomori S. Tumor-associated carbohydrate antigens defining tumor malignancy: basis for development of anticancer vaccines. Adv Exp Med Biol. 2001; 491:369-402.

43. Kieber-Emmons T, Monzavi-Karbassi B, Hutchins LF, Pennisi A, Makhoul I. Harnessing benefit from targeting tumor associated carbohydrate antigens. Hum Vaccin Immunother. 2017; 13:323-331. https://doi.org/310.1080/ 21645515.21642017.21264789.

44. Vollmers HP, Brandlein S. Natural antibodies and cancer. N Biotechnol. 2009; 25:294-298.

45. Pashov A, Monzavi-Karbassi B, Kieber-Emmons T. Immune surveillance and immunotherapy: lessons from carbohydrate mimotopes. Vaccine. 2009; 27:3405-3415. https://doi.org/3410.1016/j.vaccine.2009.3401.3074

46. Pashov A, Monzavi-Karbassi B, Kieber-Emmons T. Glycan mediated immune responses to tumor cells. Hum Vaccin. 2011; 7:156-165.

47. Wang H, Deng L, Cai M, Zhuang H, Zhu L, Hao Y, Gao J, Liu J, Li X, Lin B. Annexin A4 fucosylation enhances its interaction with the NF-kB p50 and promotes tumor progression of ovarian clear cell carcinoma. Oncotarget. 2016; 7:4298-4309. https://doi.org/10.18632/ oncotarget.10226.

48. Wang A, Lu C, Ning Z, Gao W, Xie Y, Zhang N, Liang J, Abbasi FS, Yan Q, Liu J. Tumor-associated macrophages promote Ezrin phosphorylation-mediated epithelialmesenchymal transition in lung adenocarcinoma through FUT4/LeY up-regulation. Oncotarget. 2017; 8:2824728259. https://doi.org/28210.18632/oncotarget.16001.

49. Liang YJ, Wang CY, Wang IA, Chen YW, Li LT, Lin CY, Ho MY, Chou TL, Wang YH, Chiou SP, Lin YJ, Yu J. Interaction of glycosphingolipids GD3 and GD2 with growth factor receptors maintains breast cancer stem cell phenotype. Oncotarget. 2017; 8:47454-47473. https://doi. org/10.18632/oncotarget.17665.

50. Chung MH, Gupta RK, Hsueh E, Essner R, Ye W, Yee R, Morton DL. Humoral immune response to a therapeutic polyvalent cancer vaccine after complete resection of thick primary melanoma and sentinel lymphadenectomy. J Clin Oncol. 2003; 21:313-319.

51. Hansen AR, Graham DM, Pond GR, Siu LL. Phase 1 trial design: is $3+3$ the best? Cancer Control. 2014; 21:200-208.

52. Hassan M, Watari H, AbuAlmaaty A, Ohba Y, Sakuragi N. Apoptosis and molecular targeting therapy in cancer. Biomed Res Int. 2014; 2014:150845. https://doi.org/10.1155/2014/150845.

53. Kieber-Emmons T, Monzavi-Karbassi B, Wang B, Luo P, Weiner DB. Cutting edge: DNA immunization with minigenes of carbohydrate mimotopes induce functional anti-carbohydrate antibody response. J Immunol. 2000; 165:623-627.

54. Sui M, Jiang D, Hinsch C, Fan W. Fulvestrant (ICI 182,780) sensitizes breast cancer cells expressing estrogen receptor alpha to vinblastine and vinorelbine. Breast Cancer Res Treat. 2010; 121:335-345. https://doi.org/310.1007/s1054910009-10472-10544.

55. Yeh WL, Shioda K, Coser KR, Rivizzigno D, McSweeney KR, Shioda T. Fulvestrant-induced cell death and proteasomal degradation of estrogen receptor alpha protein in MCF-7 cells require the CSK c-Src tyrosine kinase. PLoS One. 2013; 8:e60889. https://doi.org/60810.61371/journal.pone.0060889.

56. Mishra AK, Abrahamsson A, Dabrosin C. Fulvestrant inhibits growth of triple negative breast cancer and synergizes with tamoxifen in ERalpha positive breast cancer by up-regulation of ERbeta. Oncotarget. 2016; 7:5687656888. https://doi.org/56810.18632/oncotarget.10871.

57. Ivascu A, Kubbies M. Diversity of cell-mediated adhesions in breast cancer spheroids. Int J Oncol. 2007; 31:1403-1413.

58. Weigelt B, Lo AT, Park CC, Gray JW, Bissell MJ. HER2 signaling pathway activation and response of breast cancer cells to HER2-targeting agents is dependent strongly on the 3D microenvironment. Breast Cancer Res Treat. 2010; 122:35-43. https://doi.org/10.1007/s10549-10009-1050210542 .

59. Weigelt B, Ghajar CM, Bissell MJ. The need for complex 3D culture models to unravel novel pathways and identify accurate biomarkers in breast cancer. Adv Drug Deliv Rev. 2014; 6970:42-51. https://doi.org/10.1016/j.addr.2014.1001.1001.

60. Xu M, Takanashi M, Oikawa K, Tanaka M, Nishi H, Isaka K, Kudo M, Kuroda M. USP15 plays an essential role for caspase-3 activation during Paclitaxel-induced apoptosis. Biochem Biophys Res Commun. 2009; 388:366-371. https://doi.org/310.1016/j.bbrc.2009.1008.1015.

61. Okano J, Rustgi AK. Paclitaxel induces prolonged activation of the Ras/MEK/ERK pathway independently of activating the programmed cell death machinery. J Biol Chem. 2001; 276:19555-19564. 
62. Oyaizu H, Adachi Y, Taketani S, Tokunaga R, Fukuhara S, Ikehara S. A crucial role of caspase 3 and caspase 8 in paclitaxel-induced apoptosis. Mol Cell Biol Res Commun. $1999 ; 2: 36-41$.

63. Lu KH, Lue KH, Chou MC, Chung JG. Paclitaxel induces apoptosis via caspase-3 activation in human osteogenic sarcoma cells (U-2 OS). J Orthop Res. 2005; 23:988-994.

64. Yan LM, Lin B, Zhu LC, Hao YY, Qi Y, Wang CZ, Gao S, Liu SC, Zhang SL, Iwamori M. Enhancement of the adhesive and spreading potentials of ovarian carcinoma RMG-1 cells due to increased expression of integrin alpha5betal with the Lewis Y-structure on transfection of the alpha1,2-fucosyltransferase gene. Biochimie. 2010; 92:852-857. https://doi.org/810.1016/j. biochi.2010.1002.1012.

65. Wang C, Yan L, Wang Y, Lin B, Liu S, Li Q, Gao L, Zhang $\mathrm{S}$, Iwamori M. Overexpression of Lewis(y) antigen protects ovarian cancer RMG-1 cells from carboplatin-induced apoptosis by the upregulation of Topo-I and Topo-II beta. Anat Rec (Hoboken). 2011; 294:961-969. https://doi. org/910.1002/ar.21398.

66. Maher J, Wilkie S, Davies DM, Arif S, Picco G, Julien S, Foster J, Burchell J, Taylor-Papadimitriou J. Targeting of Tumor-Associated Glycoforms of MUC1 with CAR T Cells. Immunity. 2016; 45:945-946. https://doi.org/910.1016/j. immuni.2016.1010.1014.

67. Wang Y, Geldres C, Ferrone S, Dotti G. Chondroitin sulfate proteoglycan 4 as a target for chimeric antigen receptorbased T-cell immunotherapy of solid tumors. Expert Opin Ther Targets. 2015; 19:1339-1350. https://doi.org/1310.15 17/14728222.14722015.11068759.

68. Yvon E, Del Vecchio M, Savoldo B, Hoyos V, Dutour A, Anichini A, Dotti G, Brenner MK. Immunotherapy of metastatic melanoma using genetically engineered GD2specific T cells. Clin Cancer Res. 2009; 15:5852-5860. https://doi.org/5810.1158/1078-0432.CCR-5808-3163.

69. Prapa M, Caldrer S, Spano C, Bestagno M, Golinelli G, Grisendi G, Petrachi T, Conte P, Horwitz EM, Campana D, Paolucci P, Dominici M. A novel anti-GD2/4-1BB chimeric antigen receptor triggers neuroblastoma cell killing. Oncotarget. 2015; 6:24884-24894. https://doi. org/24810.18632/oncotarget.24670.

70. Thomas S, Straathof K, Himoudi N, Anderson J, Pule M. An Optimized GD2-Targeting Retroviral Cassette for More Potent and Safer Cellular Therapy of Neuroblastoma and Other Cancers. PLoS One. 2016; 11:e0152196. https://doi. org/0152110.0151371/journal.pone.0152196.

71. Ritchie DS, Neeson PJ, Khot A, Peinert S, Tai T, Tainton K, Chen K, Shin M, Wall DM, Honemann D, Gambell P, Westerman DA, Haurat J, et al. Persistence and efficacy of second generation CAR T cell against the LeY antigen in acute myeloid leukemia. Mol Ther. 2013; 21:2122-2129. https://doi.org/2110.1038/mt.2013.2154.

72. Brenner MK. CAR T cells for acute myeloid leukemia: the LeY of the land. Mol Ther. 2013; 21:1983-1984. https://doi. org/1910.1038/mt.2013.1234.

73. Rosenberger WF, Haines LM. Competing designs for phase I clinical trials: a review. Stat Med. 2002; 21:2757-2770.

74. Steplewski Z, Lubeck MD, Scholz D, Loibner H, McDonald Smith J, Koprowski H. Tumor cell lysis and tumor growth inhibition by the isotype variants of MAb BR55-2 directed against Y oligosaccharide. In Vivo. 1991; 5:79-83.

75. Brunner E, Domhof S, Langer F. Nonparametric Analysis of Longitudinal Data in Factorial Experiments. New York, NY: John Wiley \& Sons, Inc.; 2001. 288 p. 